\title{
Composite cable-stayed bridges: state of the art
}

1 José J. Oliveira Pedro PhD Assistant Professor, University of Lisbon, Lisbon, Portugal; Civil Engineer, GRID Consulting Engineers, Lisbon, Portugal
2 António J. Reis $\mathrm{PhD}$

Professor, University of Lisbon, Lisbon, Portugal; Technical Director, GRID Consulting Engineers, Lisbon, Portugal

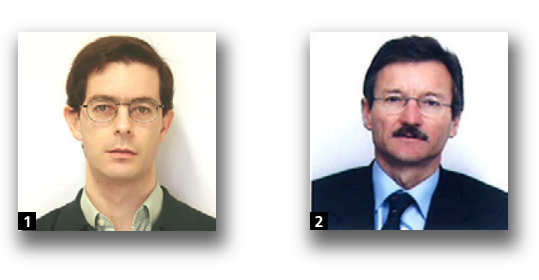

The notable developments in composite cable-stayed bridges over the past $\mathbf{5 0}$ years are presented. Reference is made to modern designs and construction methods of medium- and long-span highway decks and highway and railway composite truss decks. Future trends in composite cable-stayed bridges are discussed, referring especially to the prospect of future developments in the field of materials, cables and bridge designs.

\section{Composite cable-stayed developments}

Cable-stayed structures are elegant and efficient solutions for bridges. In the past 50 years, the range of these bridges has been steadily increasing and they are currently the most used for medium and long spans. For spans over $1000 \mathrm{~m}$, cablestayed bridges can now compete with suspension bridges.

Design and construction of cable-stayed bridges can be modified to overcome any difficulty, being a very aesthetically pleasing type of structure. These features have contributed to their growing success and continuous design and construction developments.

A deck suspended by stay cables and supported by piers and pylons forms the superstructure of a cable-stayed bridge. All these structural elements may have many configurations, which create a variety of possible solutions. This feature allows cable-stayed bridges to be used in a large range of spans, from small pedestrian urban crossings to road decks with very long spans, such as the Tatara Bridge in Japan (1999) and the Normandy Bridge in France (1995), with main spans of $890 \mathrm{~m}$ and $856 \mathrm{~m}$, respectively; also the more recently finished Stonecutters Bridge, Hong Kong (2009), Sutong Bridge, Shanghai (2008) and Russky Island Bridge, Vladivostok (2012) with main spans, respectively, of $1018 \mathrm{~m}, 1088 \mathrm{~m}$ and $1104 \mathrm{~m}$. Longer cable-stayed bridges are now being designed, combining cable stays and suspension cables. In this respect, the Third Bosphorus Bridge in Istanbul, presently under construction with a $1408 \mathrm{~m}$ long main span, will be a leading example.
The increase in span required lighter and stronger deck cross-sections. Steel decks adopting box girder cross-sections made by orthotropic plates are suitable for very long spans. For cable-stayed bridges with spans up to $600 \mathrm{~m}$, and possibly $700 \mathrm{~m}$, composite steel-concrete decks may be considered as the most efficient and competitive solution, as confirmed by the variety of composite steel-concrete decks built in the past 20 years (Figure 1) (Leonhardt and Zellner, 1991; Svensson, 1999, 2012; Taylor, 1994, 2001; Walther et al., 1985).

The use of bridge decks suspended by stays dates from the nineteenth century. However, only in the past 50 years have significant developments occurred, mainly due to progress in the materials and methods of construction, as well as in computation tools and numerical analysis models.

The Strömsund Bridge, completed in Sweden in 1955, is usually referred to as the first modern cable-stayed bridge (Figure 2). With a $182.6 \mathrm{~m}$ long main span, the deck adopted a concrete slab supported on a steel grid. However, the deck slab had the unique function of transmitting the wheel loads to the steel structure, and did not work as a composite for the horizontal component from the stays. In fact, the first time horizontal stay forces were transmitted to the deck slab was on the bridge built in 1956 in Büchenauer, Germany (Svensson, 1999).

The term 'composite' has been assigned to a wide variety of cable-stayed bridges. Four deck types using 


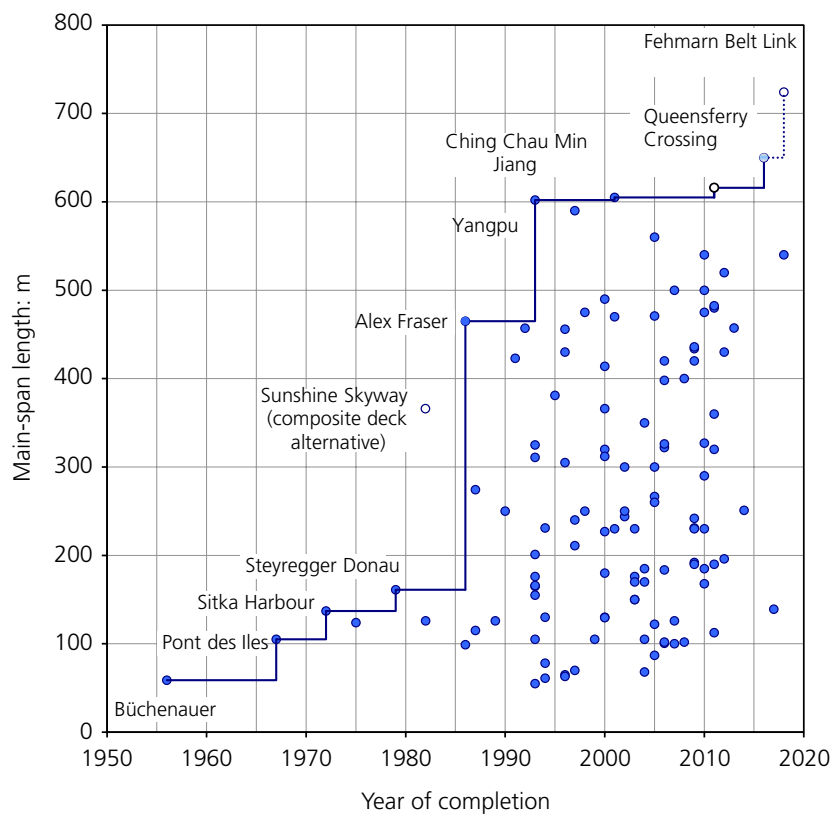

Figure 1. Composite cable-stayed bridge main span length evolution

structural steel and reinforced concrete can be identified (Svensson, 2012)

(a) composite deck sections having a concrete slab on the top of a steel structure

(b) hybrid decks usually formed by an all-steel section in the main span with prestressed concrete sections in the side spans

(c) prestressed concrete deck sections with steel cross-girders or other transverse steel elements

(d) steel deck sections with the top orthotropic plate stiffened by a reinforced concrete wearing surface, a bituminous or an epoxy resin layer.

In addition, small pedestrian decks using composite fibre materials are also referred to as 'composite', but not using steel and concrete.

A composite steel-concrete cable-stayed deck is generally understood as being composed of a steel grid with a concrete slab on the top, which together provide the stiffness and resistance to the applied bending moments and axial forces of the deck. This definition excludes deck types $(b),(c)$ and $(d)$, which are not referred to in this paper. In fact, only in decks of type (a) do the steel girders and the concrete slab work together in the longitudinal direction of the same deck cross-section.

The most common cable-stayed composite deck consists of two longitudinal steel plate girders, suspended by stay cables, and a concrete slab supported on a grid formed by the main girders and closely spaced cross-girders. The longitudinal girders, together with the concrete deck slab, resist the high axial compressive force introduced by the cables (Taylor, 1994). With time, creep and shrinkage effects of the concrete slab induce relevant deck and pylon deformations and a transfer of slab compressive force to the longitudinal girders (Pedro, 2007; Pedro and Reis, 2010).

The use of steel allows the deck cross-section to be lightweight and high strength. It also enables deck modular prefabrication at the construction yard, with high quality control and high dimensional accuracy. In addition, the use of steel cross-sections allows fast construction of the deck, due to the easy assembly of the deck segments and the availability of all the resistant capacity immediately after erection.

The use of a concrete deck slab considerably increases deck resistance to axial loads transmitted by the stays, and provides a suitable platform for supporting the highway/footway surfacing or the rail ballast and/or rail trackwork. Precast slab panels, made with reinforced concrete of high strength and with high dimensional accuracy, enhance the speed of deck construction. Assembling steel and concrete together enables a lightweight deck solution, easy and fast to build, with high quality and durability.

In the two decades following the construction of the Strömsund and Büchenauer bridges, several cable-stayed bridges were built, but only a few with a composite deck. In 1972, the Silka-Harbour Bridge was completed in Alaska, which is frequently referred to as the first road composite cable-stayed bridge (Podolny and Scalzi, 1976). With a $137 \mathrm{~m}$ long main span, the deck was formed by two main steel box girders and a concrete slab, suspended only on two sections $45 \mathrm{~m}$ away from the steel pylons. However, for the Expo of 1967 in Montreal, a road and city-train bridge was built with two simply supported spans $105 \mathrm{~m}$ long, composed of two longitudinal composite box girders and suspended by cable stays at mid-span only (Troitsky, 1988).

It took until the end of the 1970s for a long-span composite cable-stayed bridge, such as the Hooghly Bridge in Calcutta (India), to be designed. With a main span of $457 \mathrm{~m}$, it was designed between 1978 and 1982, although construction only ended in 1992. Meanwhile, in 1982, a composite deck was also proposed for the Sunshine Skyway cable-stayed bridge in Florida, USA. With a $366 \mathrm{~m}$ long main span, the composite deck proved to be economically competitive, losing by a small margin to the prestressed concrete solution (Svensson et al., 1986; Zellner et al., 1984). A very similar deck was adopted in 1986 as an alternative deck design for the Alex Fraser Bridge 


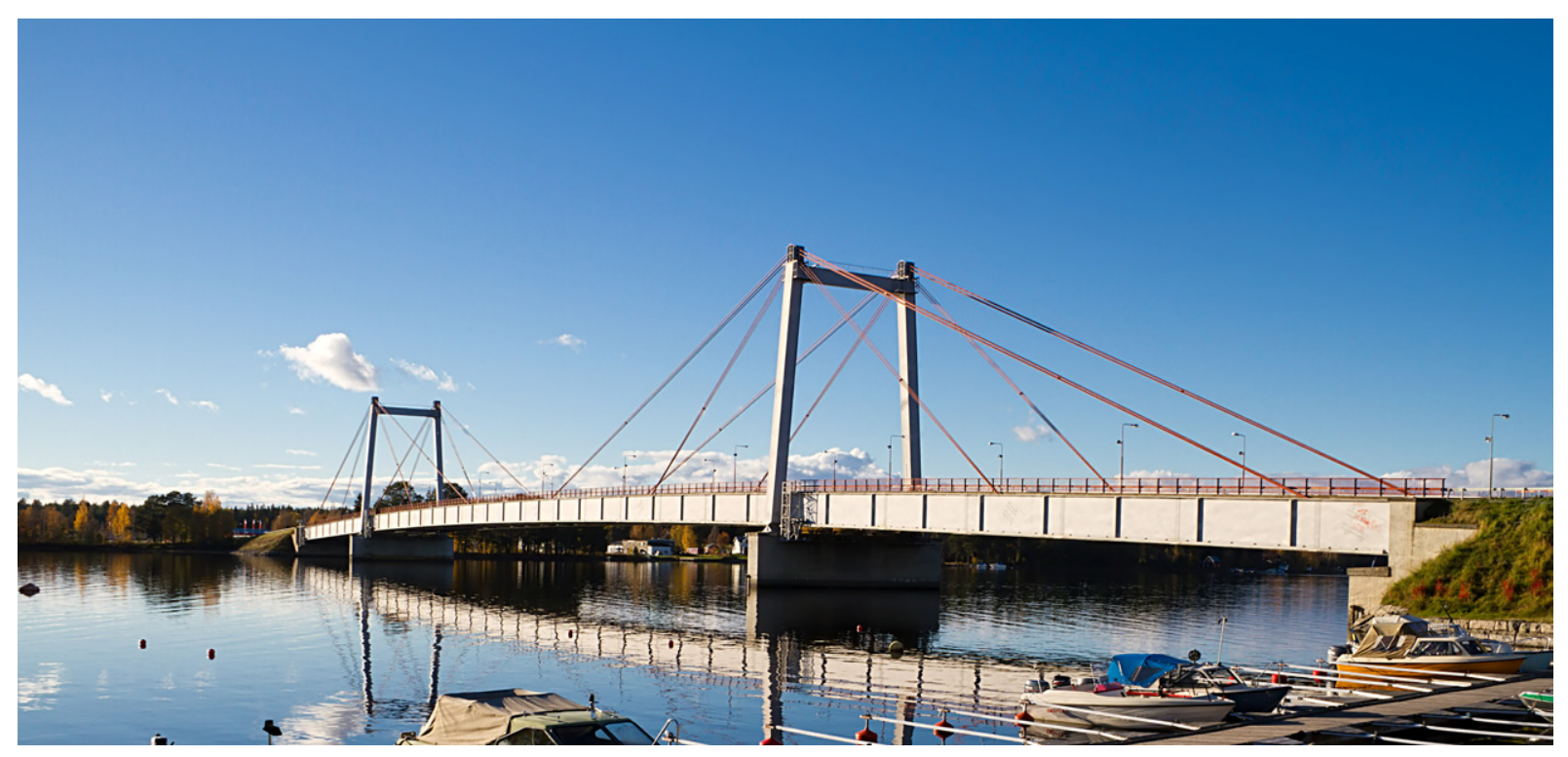

(a)

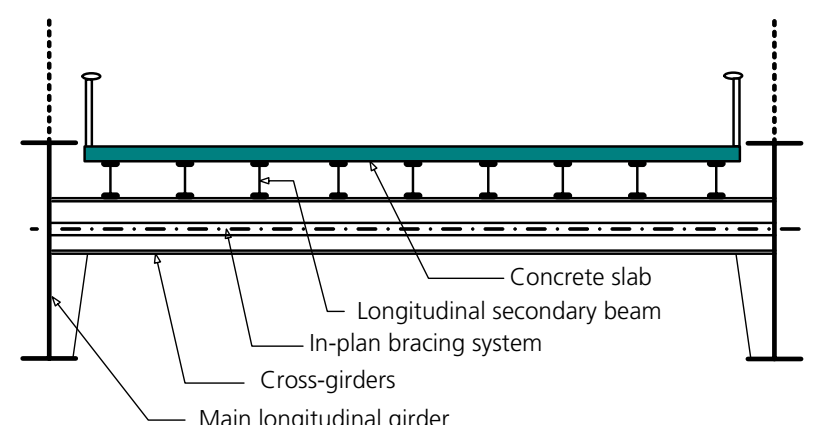

(b)

Figure 2. (a) Strömsund Bridge, Sweden (1955) (photograph by Lars Falkdalen Lindahl); (b) deck cross-section

in Vancouver, Canada (Taylor and Torrejon, 1987). This $465 \mathrm{~m}$ long main span deck held the cable-stayed bridge world record for several years (Figure 3).

The number of composite steel-concrete decks increased remarkably in the following 25 years (Figure 1). This was due to their economic competitiveness, mainly in the long-span range, but also in some particular conditions of medium- and small-span bridges. The design developments of this deck type contributed to its success. In fact, the first cablestayed bridges, like the Strömsund Bridge, had a rather complex deck, formed by the concrete slab supported by a group of longitudinal stringers that transmitted the vertical loads to the transverse cross-girders. The main longitudinal girders received the vertical loads from the cross-girders and were suspended by the stay cables in only a few sections along the span.
The composite decks proposed since the late 1970s and 1980s adopted a simpler deck. Reducing the space between stay cables, more slender longitudinal girders directly suspended by closely spaced cables, were feasible. The wide spacing of the main girders required relatively deep crossgirders. The logical option was therefore to place them closely spaced, which provided lateral restraint to the main girders and eliminated the need for diaphragms and lateral bracing. Furthermore, closely spaced cross-girders allow for the use of a slender and lighter deck slab, precast in panels to speed up construction.

Modern composite cable-stayed bridge designs can be grouped into three categories.

- Long-span highway bridges (with main span lengths over 200-250 $\mathrm{m}$ and slender decks, usually formed by twin plate 


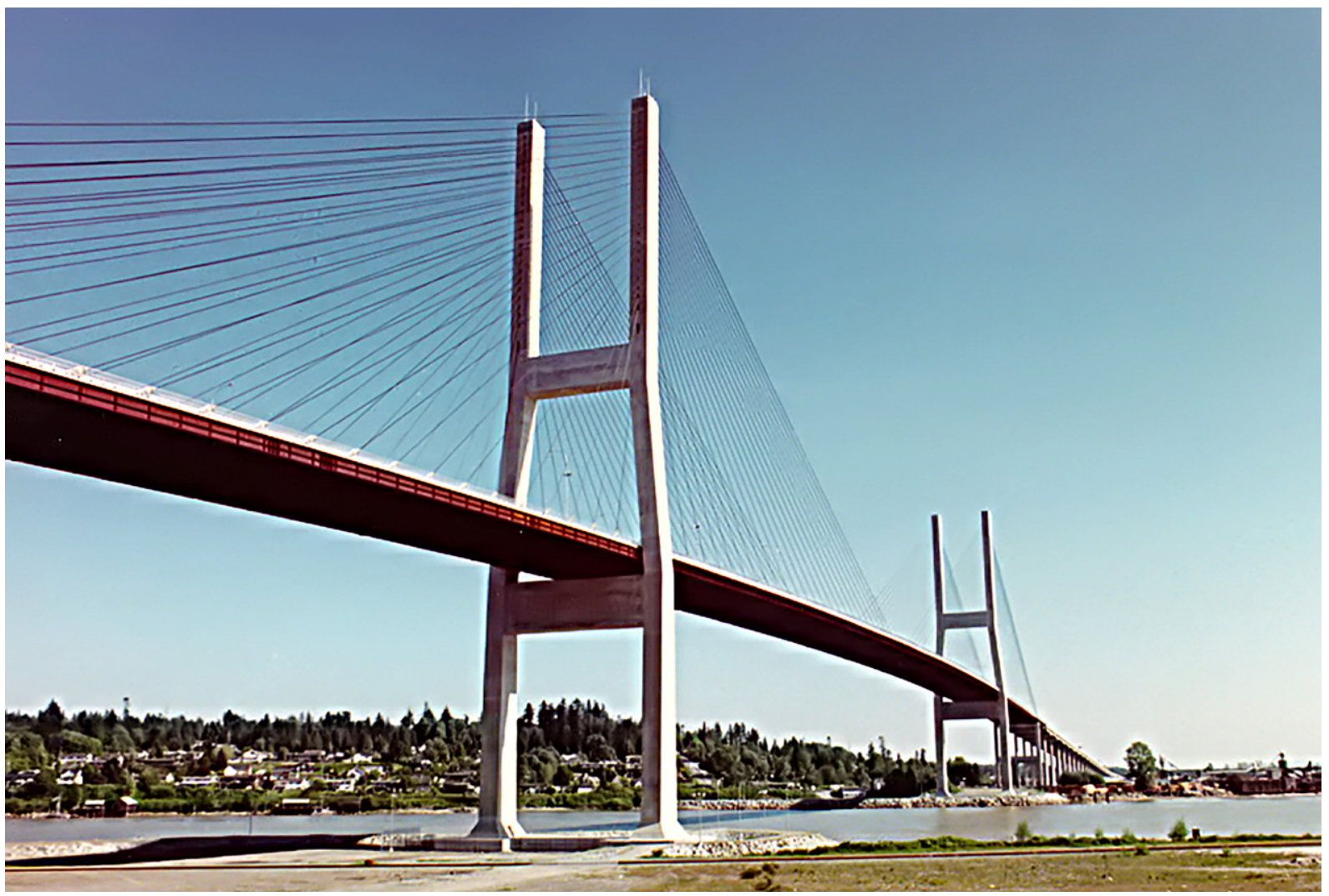

(a)

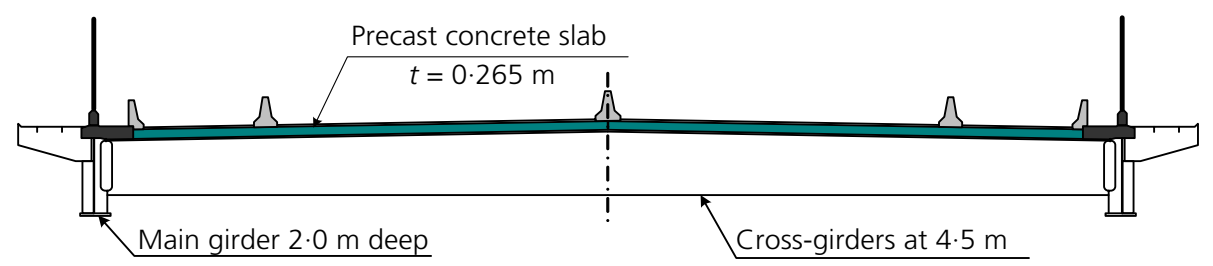

(b)

Figure 3. (a) Alex Fraser Bridge, Canada (1986) (photograph by Peter Taylor/Buckland \& Taylor); (b) deck cross-section

girders with lateral suspension and built by the balanced cantilever method).

- Medium-span highway bridges (with main spans smaller than 200-250 $\mathrm{m}$ and more diverse deck cross-sections, suspension systems and construction methods).

- Cable-stayed bridges with composite truss decks.

\section{Design of long-span highway bridges}

Modern long-span highway bridges adopt thinner and lighter decks, providing savings in the deck, cables, piers and foundations. The deck slenderness (defined as the length/depth ratio of the main span) has progressively increased, currently ranging between 100 and 300 .

The Alex Fraser Bridge was the first to adopt a very slender deck, only $2.27 \mathrm{~m}$ deep, for a $465 \mathrm{~m}$ long main span, corresponding to a slenderness ratio of 205 . This deck was laterally supported by two closely spaced planes of stay cables that formed a three-dimensional (3D) truss by converging to the top of the pylons. This configuration was also particularly useful for the deck aerodynamic stability (Figure 4(a)). The inclined cables also introduced a longitudinal and transverse compressive force on the concrete slab. This slab was precast in panels between cross-girders avoiding expensive site formworks 


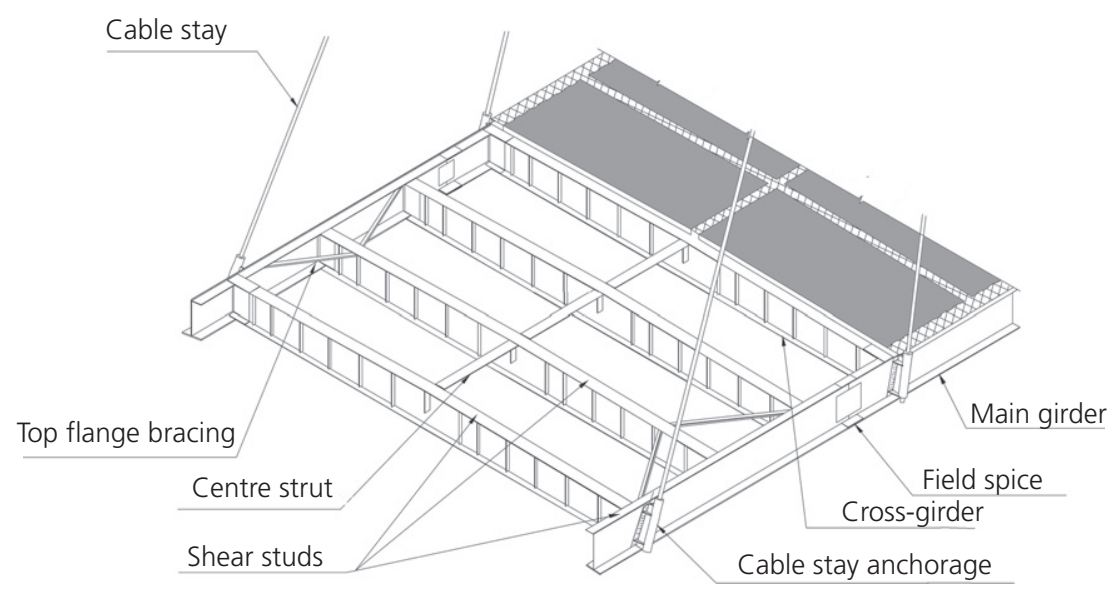

(a)

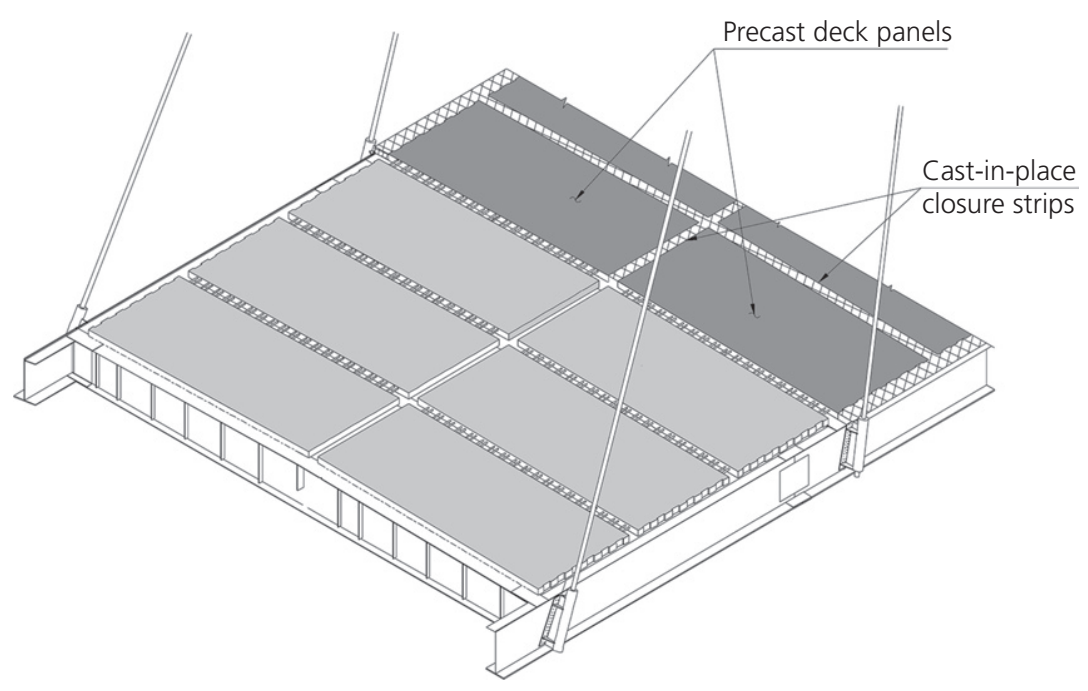

(b)

Figure 4. Typical composite cable-stayed deck structure: (a) steel section detail and (b) concrete slab executed with precast panels

and much decreasing concrete time-dependent effects. Field bolted splices provided fast and simple connections between almost identical modules, ensuring maximum repetition of prefabricated steel and concrete deck components and in situ construction procedures (Figure 4(b)) (Taylor, 1994).

Almost all highway composite cable-stayed bridges with a main span exceeding $200 \mathrm{~m}$ were constructed with the same balanced cantilever construction method. This included simple and repetitive operations: the lifting of one section comprising two steel edge girders and two or three cross-girders and connecting it to the previous section with bolted splices; lifting and placing the precast concrete deck panels, spanning between cross- girders and casting in situ the closure strips; installing a pair of cable stays anchored to the longitudinal girders.

The stay installation is typically completed in two stages: first only part of strands are stressed during erection of the steelwork; finally the remaining strands are stressed after construction of the deck slab. Still, some minor force adjustments are usually necessary after mid-span closure to achieve the final highway alignment.

This construction method was used in the construction of three major composite cable-stayed bridges built in Shanghai over the past few years, namely the Nanpu, Yangpu, and 
Xupu bridges, with $423 \mathrm{~m}, 602 \mathrm{~m}$ and $590 \mathrm{~m}$ long main spans and completed, respectively, in 1991, 1993 and 1997 (Xiang, 1999). The Ching Chau Min Jiang and Erqi Yangtze River bridges, with $605 \mathrm{~m}$ and $616 \mathrm{~m}$ long main spans, came into service in 2001 and 2011, being now the two longest composite cable-stayed spans. In the Yangpu and Xupu bridges, the two main plate girders were replaced by two rectangular box girders, with the aim of increasing the resistance to the longitudinal compressive forces introduced by the stays. This design concept can be used for longer-span decks, on which the lateral wind bending moments of the cross-section near the pylons can become critical when combined with the maximum in-service compressive force they already experience (Taylor, 2001).

The Ting Kau Bridge, completed in 1998 in Hong Kong (Figure 5), has a singular design. With two main spans $448 \mathrm{~m}$ and $475 \mathrm{~m}$ long, this $42.8 \mathrm{~m}$ wide deck has four main plate girders only $1.51 \mathrm{~m}$ deep and four stay cable planes, featuring the following particularities: a very high slenderness ratio of 271 for the longest span; very long stays from the top of the central pylon to the lateral pylons at deck level, with the aim of stabilising the central pylon; transverse stays also for pylon stabilisation (Bergermann and Schlaich, 1998).

Years before, the Baytown Bridge, over the Houston Ship Channel, USA (1995; see Figure 6), also adopted two parallel decks, each one $23.8 \mathrm{~m}$ wide and composed of twin plate girders suspended by stays to the diamond-shaped pylons. This design has proved to be a very stable solution for a structure located in a tornado region (Svensson and Lovett, 1994). This bridge design also presented for the first time an alternative solution of the traditional cantilever scheme. In fact, each segment was designed to be lifted with the concrete slab,

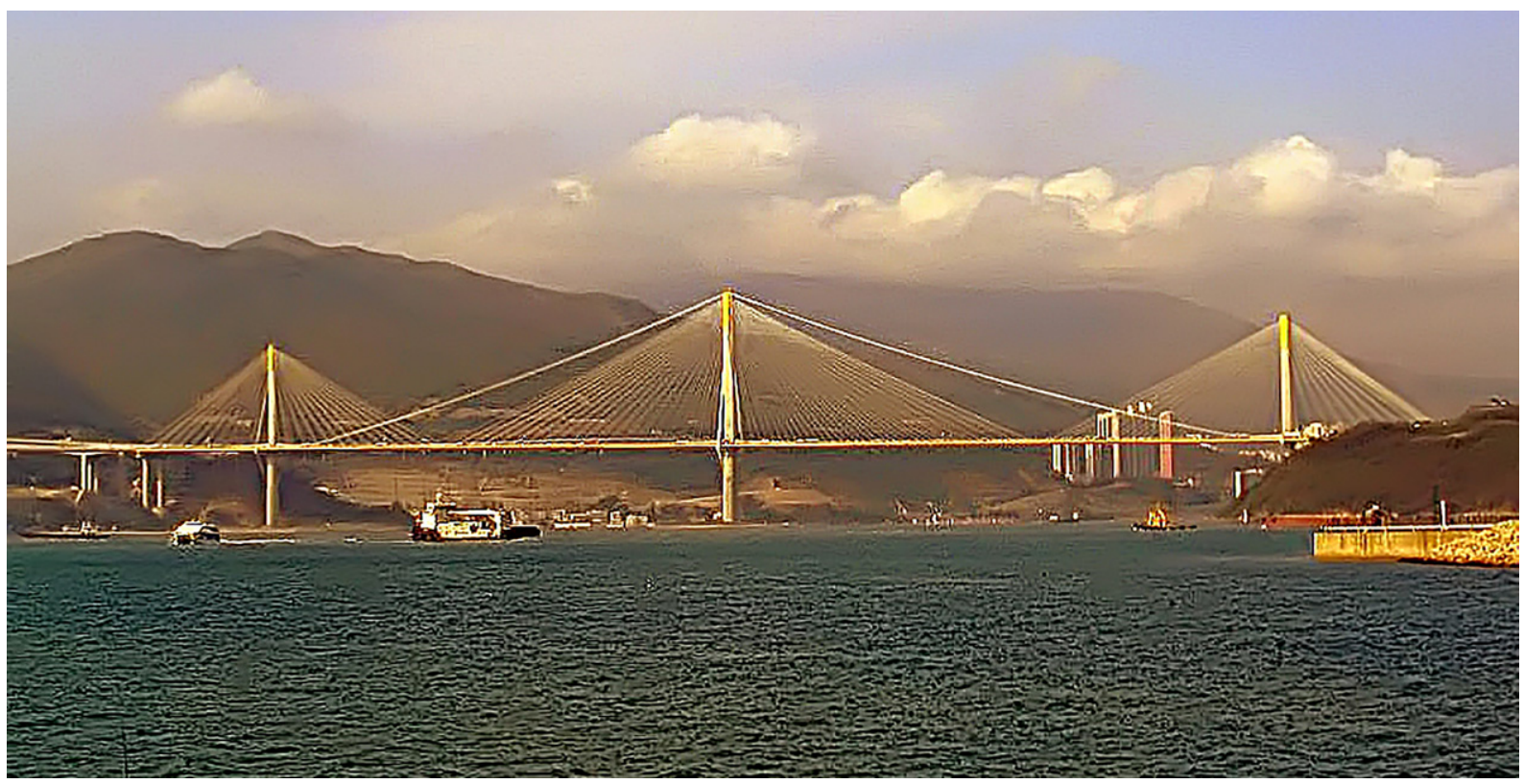

(a)

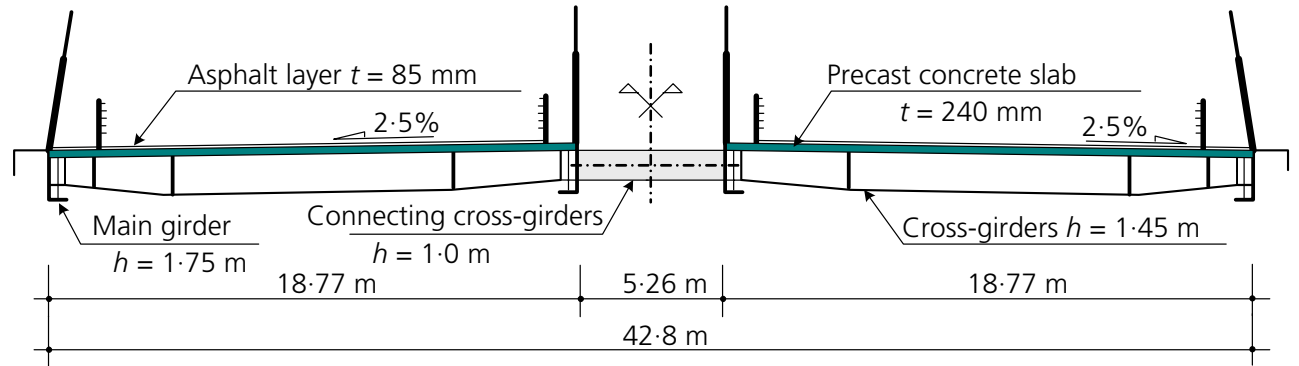

(b)

Figure 5. (a) Ting Kau Bridge, Hong Kong (1988) (photograph by Baycrest); (b) deck cross-section 


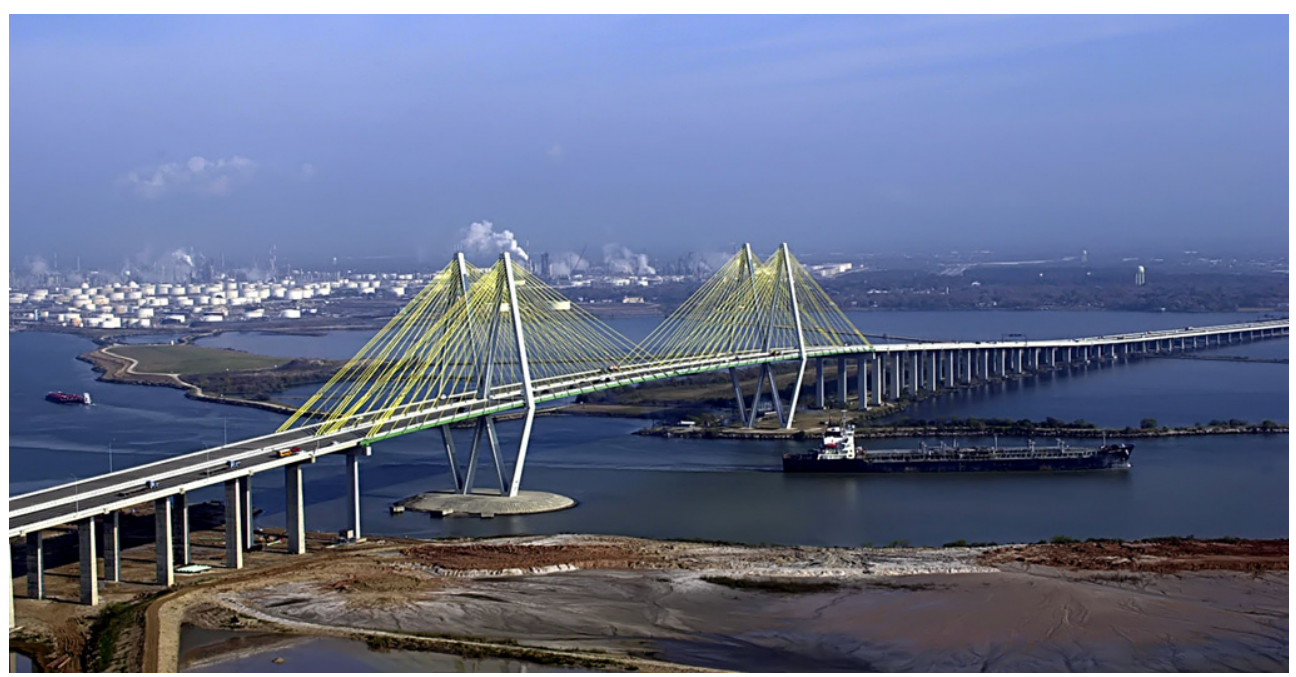

(a)

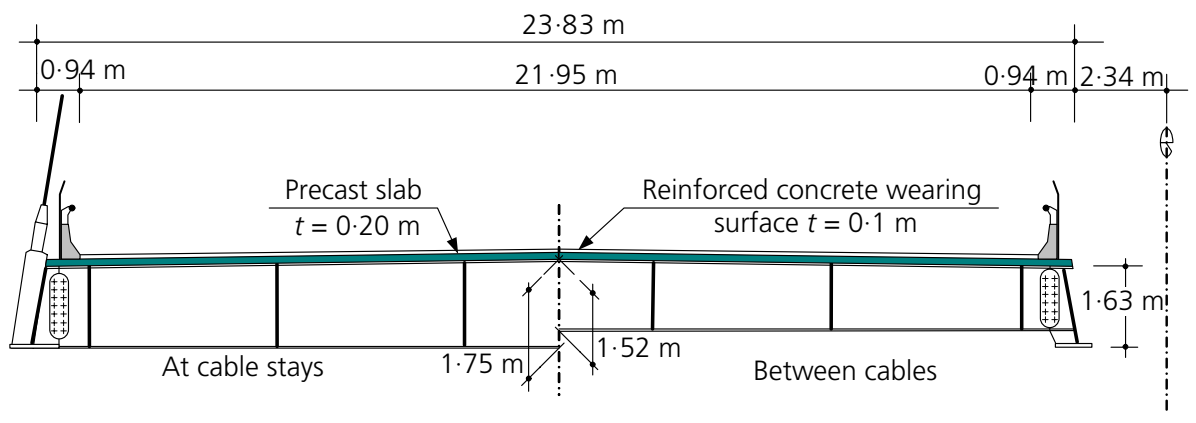

(b)

Figure 6. (a) Baytown Bridge, TX, USA (1995) (courtesy of the US

Coast Guard); (b) deck cross-section

speeding up the construction even more and saving some structural steel. The main disadvantage of this solution was the need for moving and lifting segments of greater dimensions and weights, which produced important additional stresses at the cantilever deck already in place. In the end the contractor decided to use standard precast slabs connected by cast-inplace joints. As a result, the loss of composite action of the cross-girders for dead loads required an additional $640 \mathrm{t}$ of structural steel $(17 \%$ additional steel weight, which corresponded to an increase in the structural steel ratio from $121 \mathrm{~kg} / \mathrm{m}^{2}$ to $141 \mathrm{~kg} / \mathrm{m}^{2}$ of deck surface) (Tang, 1994).

More recently, the same solution has been adopted in several composite cable-stayed bridges, such as the Rion-Antirion Bridge in Greece (2005), the Second Severn Crossing Bridge, South Wales, UK (1996), the two Industrial Ring Road Bridges in Thailand (2006) and the Erqi Yangtze River Bridge, China (2011), with two consecutive spans of $616 \mathrm{~m}$. The RionAntirion Bridge has three consecutive very flexible $560 \mathrm{~m}$ long spans and a total length of $2252 \mathrm{~m}$, proving that cable-stayed bridges could successfully overcome very long distances, without the need for a super-long suspended span, even if very stiff pylons with considerable visual impact were required (Figure 7) (Teyssandier, 1997).

In the $34.6 \mathrm{~m}$ wide deck of the Second Severn Crossing Bridge, innovative cross-girders made of Pratt-type trusses (Figure 8) replaced standard plate girders (Combault et al., 1994). The concrete slab was also cast in advance in the yard. Only a remaining strip of the slab was cast in place and, after concrete strengthening, a pair of cables was tensioned in a single step, speeding up the deck erection.

In the two Industrial Ring Road Bridges, a wide deck crosssection used plate girder cross-girders of considerable height, reaching $3.2 \mathrm{~m}$ deep at the mid-span section, to resist the transverse sagging bending moment (Farquhar, 2008). In fact, design practice has shown that when lateral suspension is 


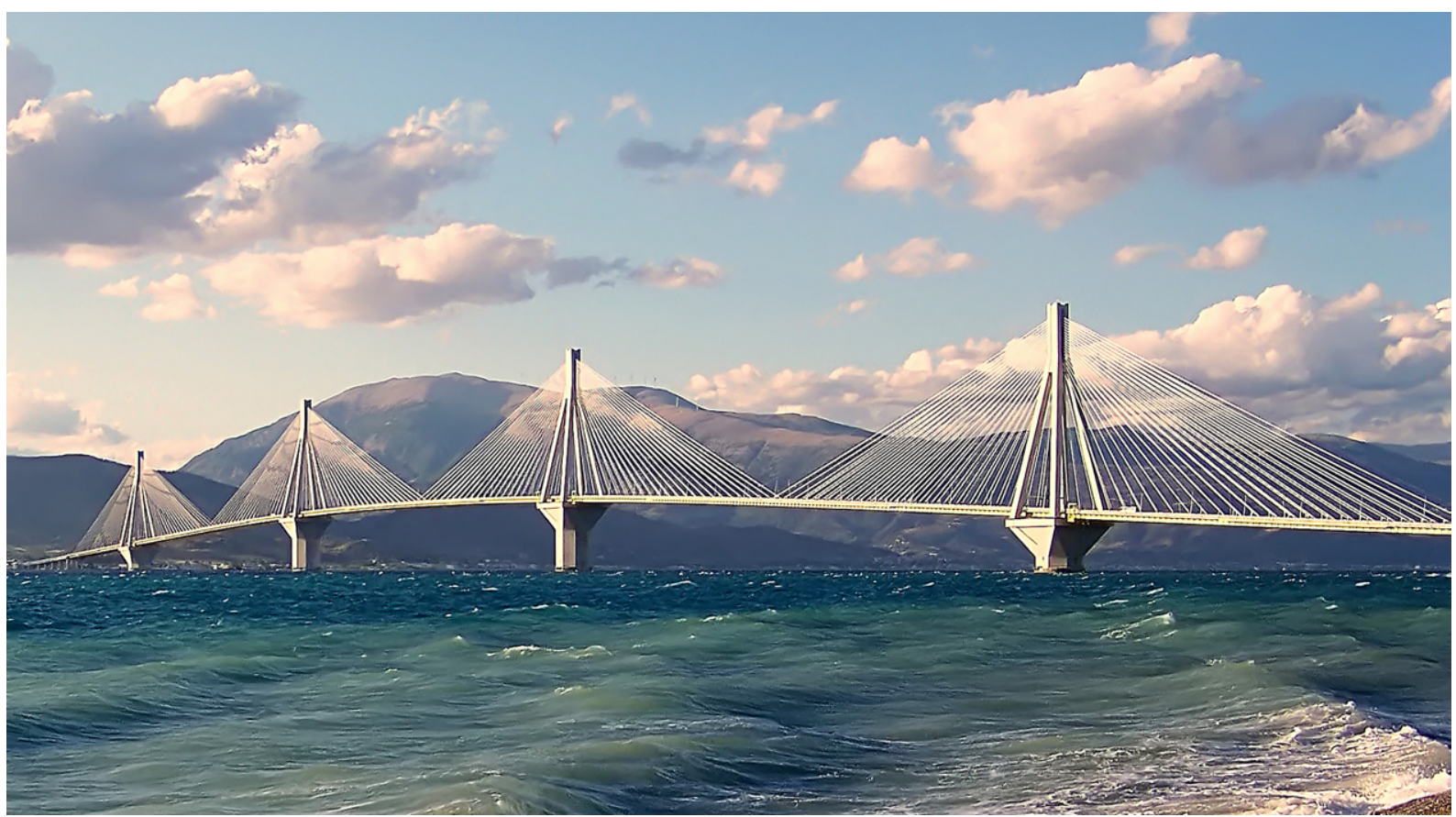

(a)

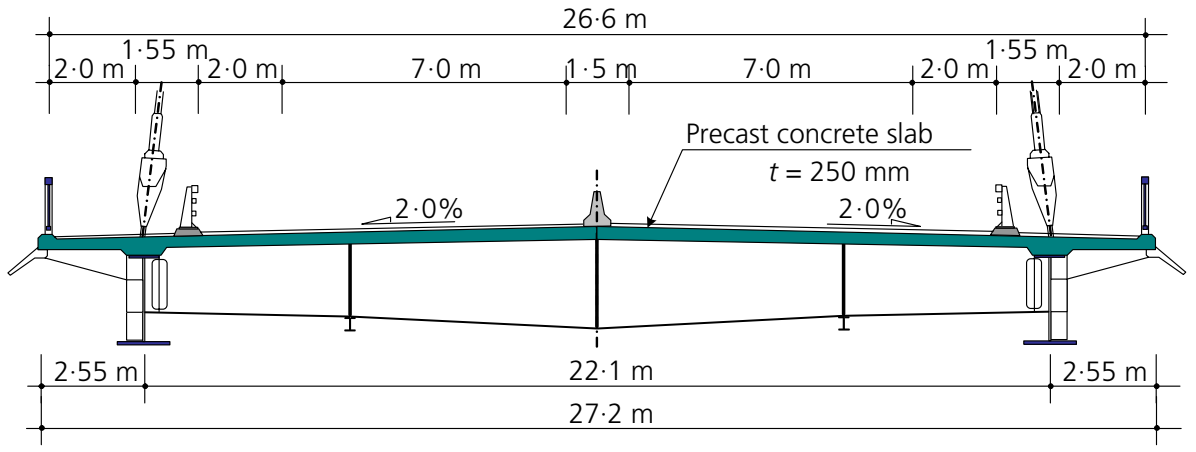

(b)

Figure 7. (a) Rion-Antirion Bridge, Greece (2005) (photograph by

Eusebius); (b) deck cross-section

adopted, the height of cross-girders including slab thickness, needs to be between 1/10th and 1/12th of the transverse spacing of the stay deck anchorages.

Due to concrete time-dependent effects, a decrease in the axial compression is observed at the deck sections. Consequently, tensile force develops throughout the in-service period, namely at mid-span sections of the slab and may cause regions of cracking (Pedro, 2007; Pedro and Reis, 2013). To prevent this effect, slab longitudinal prestressing has been used. That was the case with the Quincy Bridge, USA (1987) (Tang, 1994), the Yangpu Bridge, China (1993) (Virlogeux, 2002) and more recently the Cape-Girardeau Bridge in the USA (2004) (Hague, 2003). However, post-tensioning hampers deck construction, because it should be installed with the concrete deck slab panels connected only to the cross-girders. Only afterwards should the deck slab be connected to the longitudinal girders, to ensure that precompression remains in the deck slab, even if over time it is transferred to the longitudinal steel girders.

In the USA, composite cable-stayed bridges have experienced great developments over the past two decades, being the winning solutions of several design-built tenders. More than 


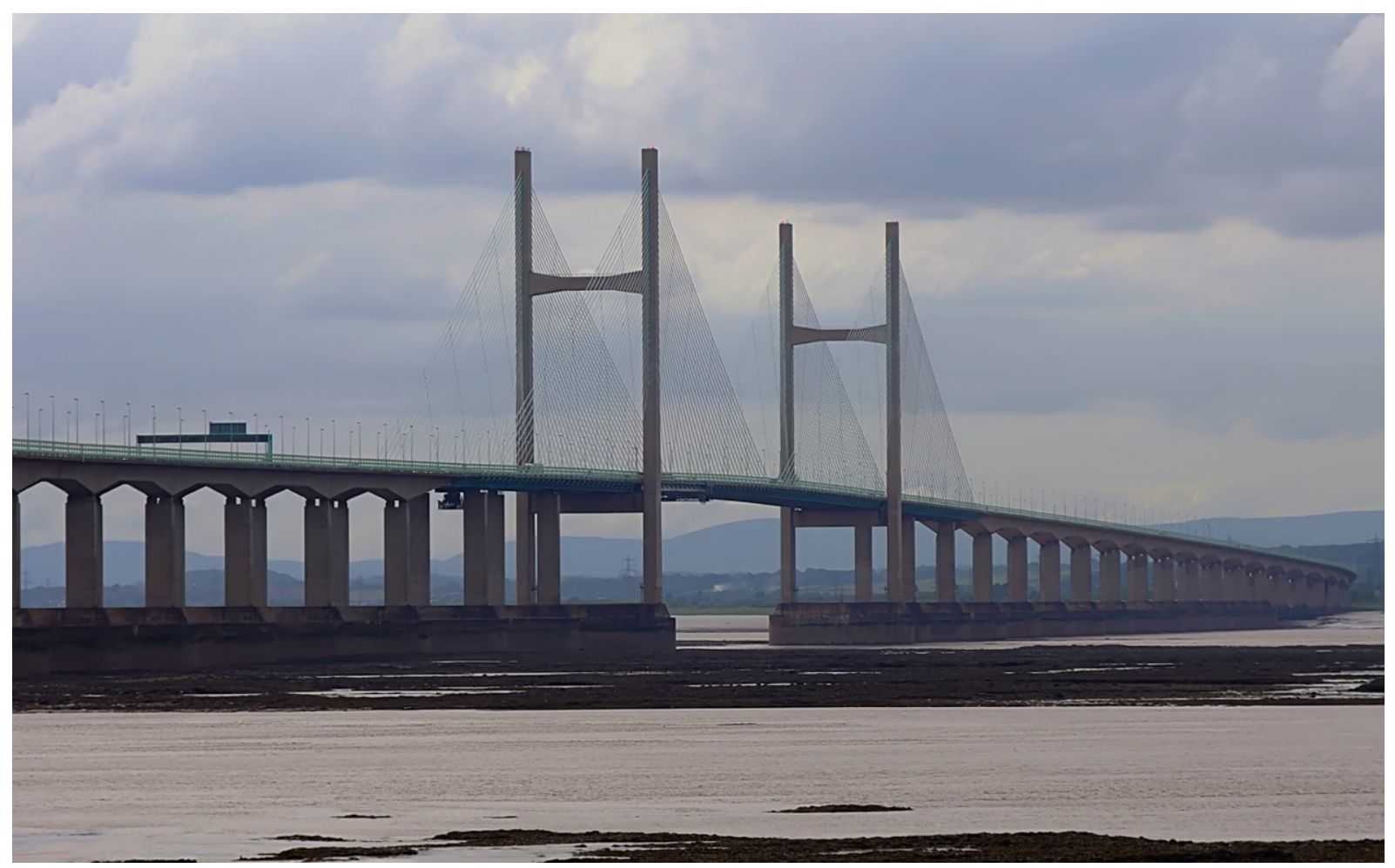

(a)

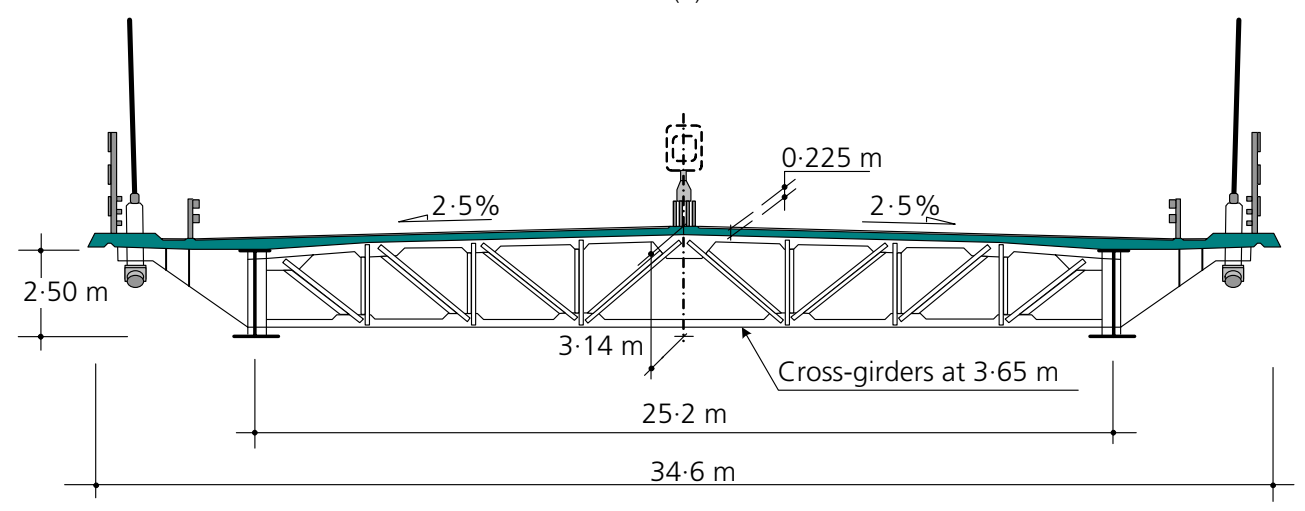

(b)

Figure 8. (a) Second Severn Crossing Bridge, South Wales, UK

(1996) (photograph by Mattbuck); (b) deck cross-section

ten composite cable-stayed bridges have been built with spans over $200 \mathrm{~m}$, and several others are presently under design or construction. Decks with two main plate girders were adopted, as well as the balanced cantilever construction method. The Arthur Ravenel Bridge (Abrahams, 2005), completed in 2005 with a $471 \mathrm{~m}$ long main span, and the John Audubon Bridge, with a $482.5 \mathrm{~m}$ long main span, presently the longest cable-stayed bridge in North America, are just two good examples.
Also in Mexico, several important composite cable-stayed bridges have been built over the years. The most recent example is the Baluarte Bridge, included in the new highway linking the Atlantic and the Pacific coasts of northern Mexico (Figure 9) (Virola, 2013). With a main span deck of $520 \mathrm{~m}$, and notably $400 \mathrm{~m}$ above the valley below, the construction of the bridge began in 2008 and it was open to traffic in 2013. The $432 \mathrm{~m}$ central part of the main span has a standard composite deck. To reduce weight, a ribbed section was used for 


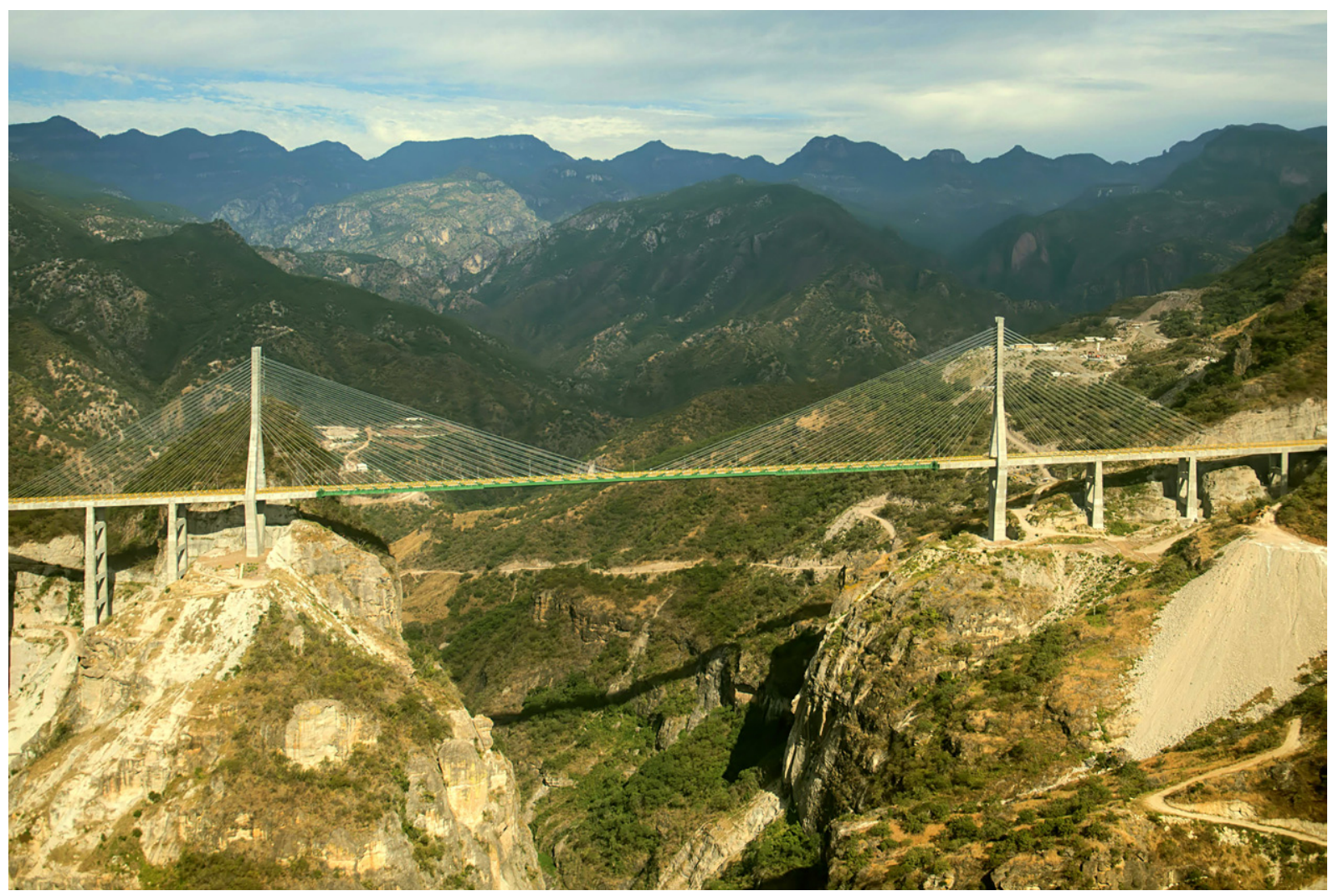

(a)

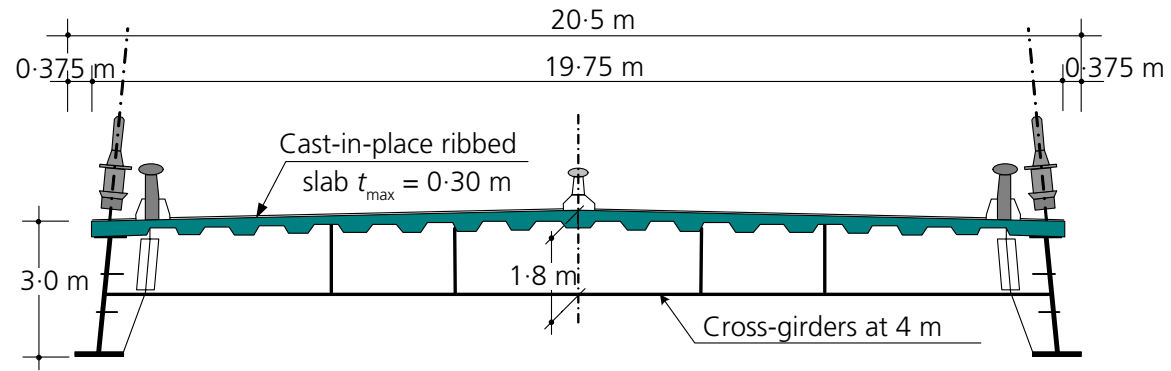

(b)

Figure 9. (a) Baluarte Bridge, Mexico (2013) (courtesy of Alfredo Guerrero/Presidency of Mexico); (b) deck cross-section

the deck slab panels, cast in place using corrugated steel sheets as formwork, as first proposed by Taylor (2001). The much shorter concrete side spans were constructed beforehand, using two lateral rectangular box girders linked by steel cross-girders that support the concrete ribbed slab.

Among several long-span cable-stayed bridges presently under construction, mostly in China, the Queensferry Crossing, the third bridge across the Forth in Scotland, due to be completed by 2016 , stands out for its unique composite deck suspension system and two $650 \mathrm{~m}$ long consecutive spans (Figure 10).
With three reinforced concrete pylons located centrally, the streamlined box girder deck will be suspended by two planes of stay cables anchored in the central reserve between the two carriageways. A unique feature of this bridge is the overlapping stay cables that occur at the middle of each main span to address the stability problem of the central pylon (Curran et al., 2011). While aesthetically interesting, this feature introduces challenges to the deck closure that are unique from other cable-stayed bridges. The composite deck was proposed as an alternative arrangement, and it comprises 149 segments $12 \mathrm{~m}$ long and $40 \mathrm{~m}$ wide, prefabricated in China and Spain 


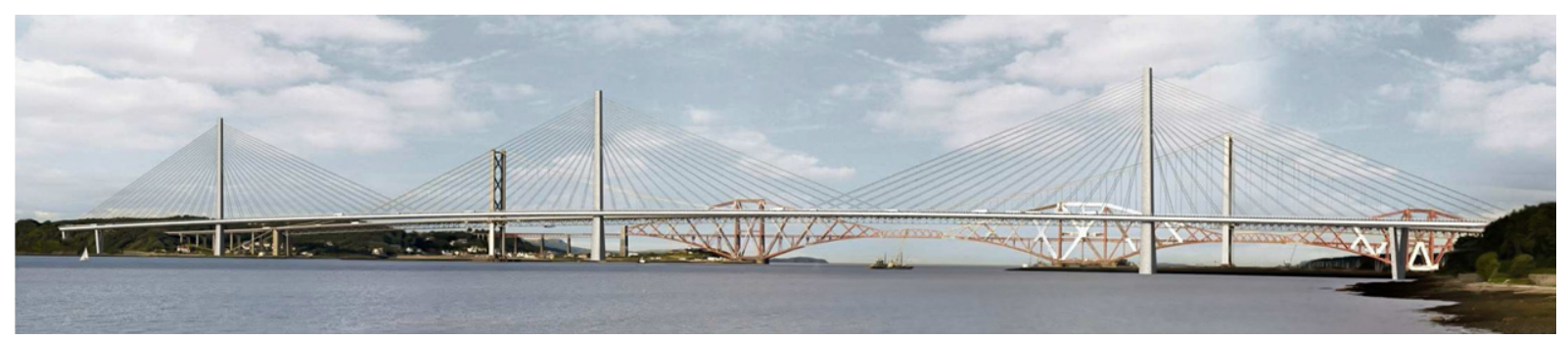

(a)

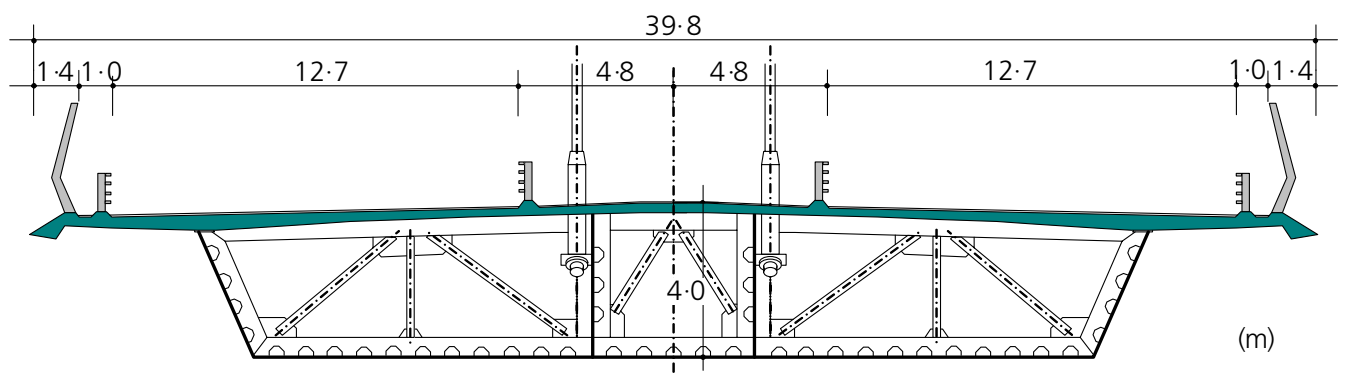

(b)

Figure 10. (a) Queensferry Crossing Bridge, Scotland (2016)

(Courtesy of Damien Keogh/Rambøll); (b) deck cross-section

(Carney and Nowak, 2011). The concrete slab is precast in the yard with the use of transverse prestressing to prevent cracking and maintain the torsional stiffness of the box cross-section. The segments will be transported on barges and erected by the balanced cantilever method.

The study of the main features of highway and railway composite cable-stayed bridges built all over the world led to some significant conclusions (Pedro, 2007; Pedro and Reis, 2013); with respect to the deck slenderness (main-span length/deck depth) (Figure 11).

- For highway girder decks, values increase from 75 to 225 with the increasing span length; slenderness tends to be approximately constant for spans over $500 \mathrm{~m}$ long.

- Beyond this range, the four-girder deck of the Ting Kau Bridge (Figure 5) has a very high slenderness ratio of 271.

- Slenderness of railway decks is much lower, with typical values below 50 , due to deformability restrictions imposed by functional requirements.

With respect to the deck self-weight, the following can be observed.

- The structural steel weight ratio per square metre of the deck is between $125 \mathrm{~kg} / \mathrm{m}^{2}$ and $300 \mathrm{~kg} / \mathrm{m}^{2}$, with an average value of $213 \mathrm{~kg} / \mathrm{m}^{2}$ (Figure 12(a)).
- The average deck self-weight ratio per square metre of the deck is $850 \mathrm{~kg} / \mathrm{m}^{2}$ (considering the weight of the structural steel and of the concrete slab), and typical values are between $700 \mathrm{~kg} / \mathrm{m}^{2}$ and $1000 \mathrm{~kg} / \mathrm{m}^{2}$ (Figure 12(b)), in agreement with the ranges proposed by several authors (Farquhar, 2008; Virlogeux, 2002).

With respect to the stay cables steel weight, the following can be noted.

- The steel weight ratio of the stays per square metre of the deck increases with the main span length, according to the boundaries of stay cable catalogues (Freyssinet, 1994, 2004) for steel, composite and concrete cable-stayed decks (Figure 13(a)).

- Plotting on the same graph the steel weight of the stays per deck square metre, for composite cable-stayed bridges, results are quite diverse.

- Railway decks always present a stay weight ratio much higher than the values recorded for road decks, due to greater deck dead and live loads.

- Assuming an equivalent main span length, $L$, for highway bridges with an asymmetrical single pylon equal to twice the real main span length (Figure 13(b)), the stay steel weight ratios per deck square metre are a much better fit.

- A quadratic trend line is almost over the average line proposed for composite decks with long spans in a stay cable catalogue (Freyssinet, 1994, 2004) (Figure 13(b)). 


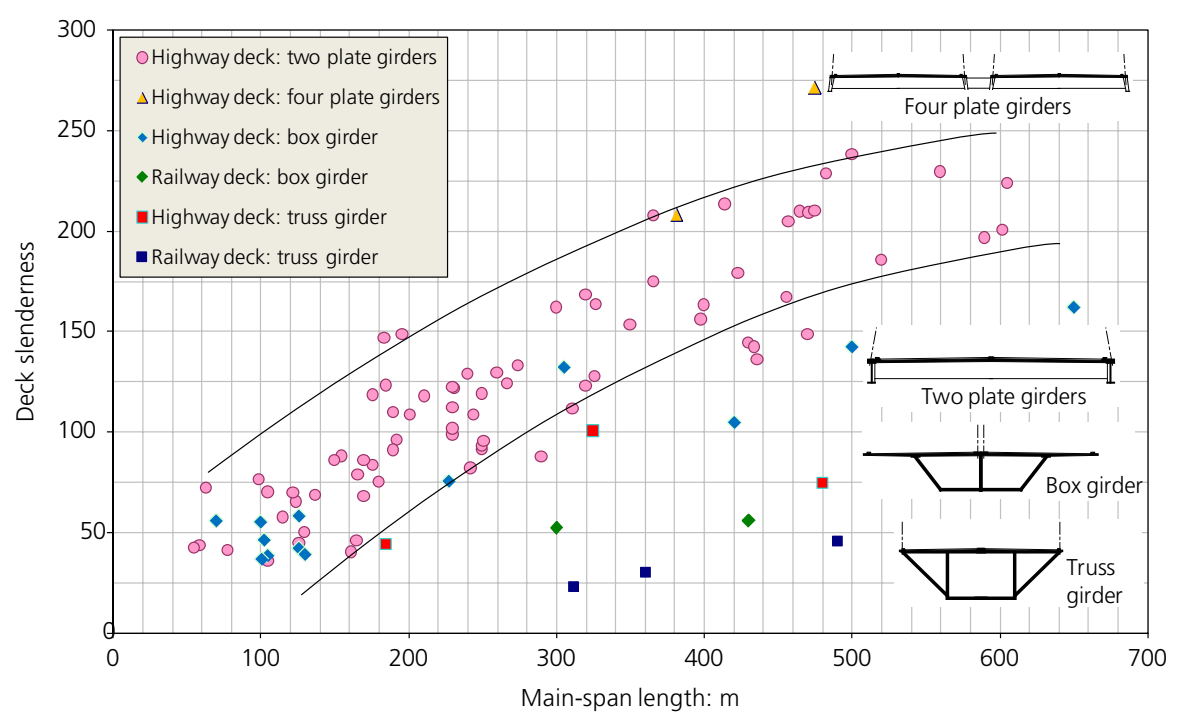

Figure 11. Deck slenderness (main-span length/deck depth)

against main span length, for composite cable-stayed bridges

\section{Design of medium-span highway bridges}

For spans up to $250 \mathrm{~m}$, cable-stayed bridges could compete with box girder bridges and arch bridges, but are rarely the most economic solution. However, a cable-stayed bridge with a slender deck may be desirable in an urban environment for aesthetics or due to difficulties in positioning the deck supports. These aspects may favour the cable-stayed solution, not only for the crossing of rivers and canals but also for spanning very wide highways and multitrack railways. Other factors favourable to a cable-stayed solution are improved aesthetics due to transparency of the structure, resulting from the reduction in the number of piers and increased slenderness of the deck, and reduction in traffic constraints during the execution.

For medium spans the regular symmetrical cable-stayed layout with a three-span straight deck and two pylons is frequently not the best solution. Asymmetrical solutions with a single pylon or with a curved deck may be more appropriate to overcome local environmental constraints (Reis et al., 1999; Virlogeux, 1990). Medium-span composite cable-stayed bridges were also designed with decks composed of two plate girders laterally suspended, erected by fast construction methods. The concrete slab on the top is still supported by closed spaced cross-girders, as on the Seyssel Bridge in France (1987; Figure 14), with a single pylon suspending a $115 \mathrm{~m}$ long main span and three side spans of $35.2 \mathrm{~m}$, with two planes of nine stays on each side (Virlogeux et al., 1985).

Decks with lateral suspension nevertheless have a major drawback, due to the visual impact of two planes of stays. The central suspension of the deck improves aesthetics but requires a deck with higher torsional rigidity, namely a box girder cross-section. The Arena Viaduct, Spain (1993; Figure 15) (Arenas and Pantaleón, 1992), with five $105 \mathrm{~m}$ inner spans, and the Alzette River Bridge in Luxembourg (1994) (Biwer et al., 1994), with two side spans $130 \mathrm{~m}$ long, are examples of medium-span composite decks with central suspension and curved in-plan highway alignments.

The Arena Viaduct cable-stayed deck was built using an unusual method. Each span was fully executed on the ground, including concreting the slab, and raised up to a height of $30 \mathrm{~m}$ by using $2600 \mathrm{t}$ capacity lifting gantries, placed at the top of the piers. Each span was then welded to the previous one. Only after erecting all the deck were the steel masts put in place and the six central stays were installed on each side of the masts (Arenas and Pantaleón, 1992).

The balanced cantilever construction method usually leads to a longer construction time, requires a detailed study of many construction stages and a rigid control over the geometry of the structure and forces/displacements of the stays during all construction stages. As an alternative, for medium-span bridges, incremental launching or erection by cranes and temporary supports has been used, as in the Seyssel and Alzette River bridges. The steel decks were launched using temporary supports, and the slabs were cast in place using mobile formworks supported on the steel structures. The same method was used in several of the medium-span cable-stayed bridges built in Finland, such as the asymmetric Kemijoki Bridge 


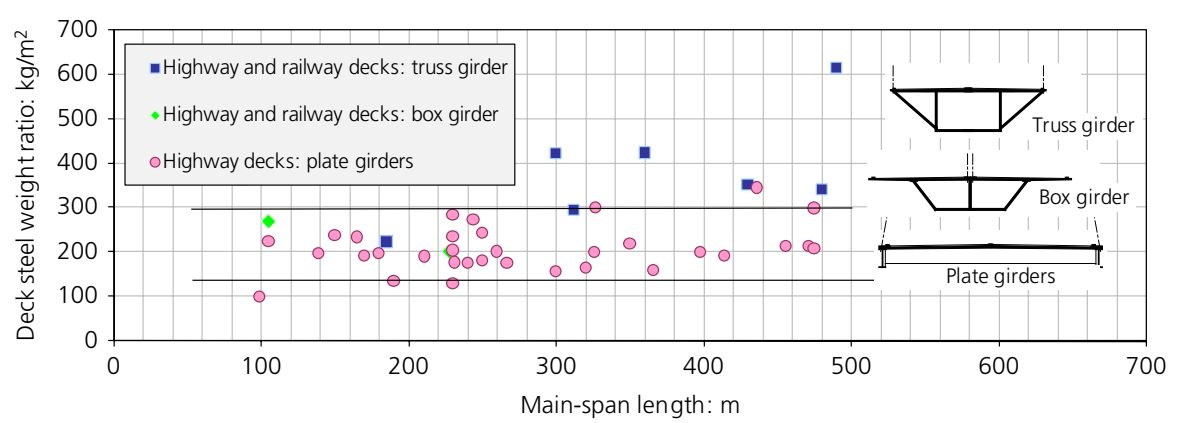

(a)

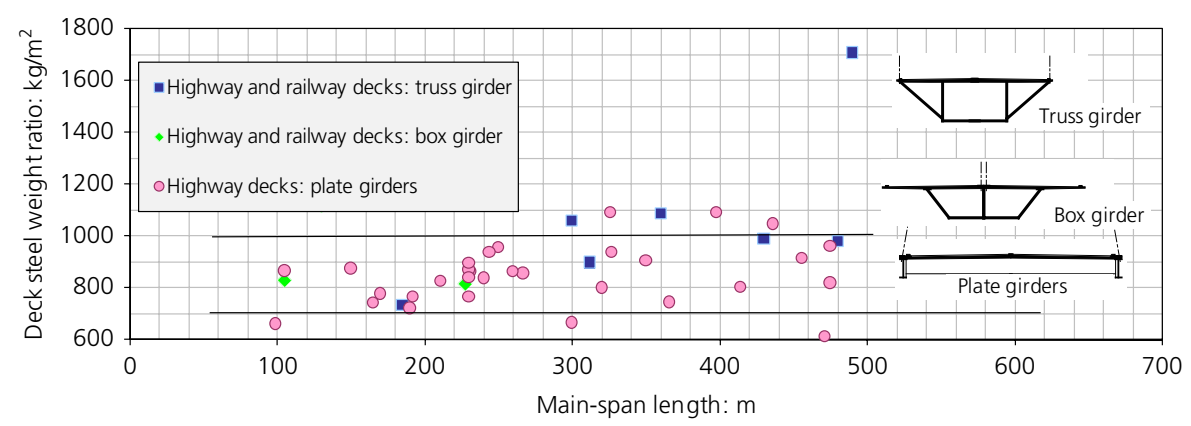

(b)

Figure 12. (a) Deck steel weight ratio and (b) deck self-weight ratio, per square metre of the deck, against main-span length, for composite cable-stayed bridges

(Figure 16), with a $126 \mathrm{~m}$ main span composite box girder deck with inclined struts supporting the cantilevers, and suspended by two central planes of stays (Vähäaho et al., 1996).

\section{Design of composite cable-stayed truss bridges}

The design of cable-stayed bridges with composite truss decks allows superstructures to be lighter than traditional prestressed concrete box girders and less deformable than steel or composite plate girder decks. By anchoring the stays at the top slab level, the horizontal compression components of the stays are transmitted mainly to the deck slab, because the truss girder is relatively flexible in the longitudinal direction when compared with the axial stiffness of the deck slab. Moreover, the autoequilibrated longitudinal forces generated by the imposed deformations of shrinkage and creep of the concrete slab are also reduced, as in the longitudinal direction each lattice girder acts as a 'harmonium', allowing the deformations and reducing internal forces due to time-dependent effects.

Karnali Bridge, completed in Nepal in 1993, was the first cable-stayed road bridge with a composite truss deck (Figure 17). This outstanding structure has a $325 \mathrm{~m}$ span, suspended by a single pylon (deck slenderness approximately
100). To reduce deck deformability, two lattice Warren girders $3 \mathrm{~m}$ deep were adopted (Arzoumanidis and Kunihiro, 1994).

For railway bridges, a stiff deck is needed to ensure train operational requirements. Truss girder decks are widely adopted in suspension bridges and in some cable-stayed bridges. In particular, composite steel-concrete truss decks combine high bending stiffness with a relatively low weight, using the concrete deck slabs to support the carriageways. Composite truss decks were adopted in the Øresund Bridge between Sweden and Denmark, and more recently in the Mercosur Bridge, the third important crossing over the Orinoco River in Venezuela.

The $490 \mathrm{~m}$ span Øresund Bridge (Figure 18) (Aso, 1999) adopted a deck with two vertical steel trusses, with a concrete slab on the top for the highway. At the bottom level, a continuous orthotropic steel deck supports two ballast boxes for high-speed lines. The construction used deck steel segments prefabricated in Spain and transported by ship to Sweden, where the slab was precast before span erection. Handling operations of these elements, $120-140 \mathrm{~m}$ long and weighing up to $6200 \mathrm{t}$, were carried out with a crane mounted on a barge. Deck segments were placed on temporary supports 


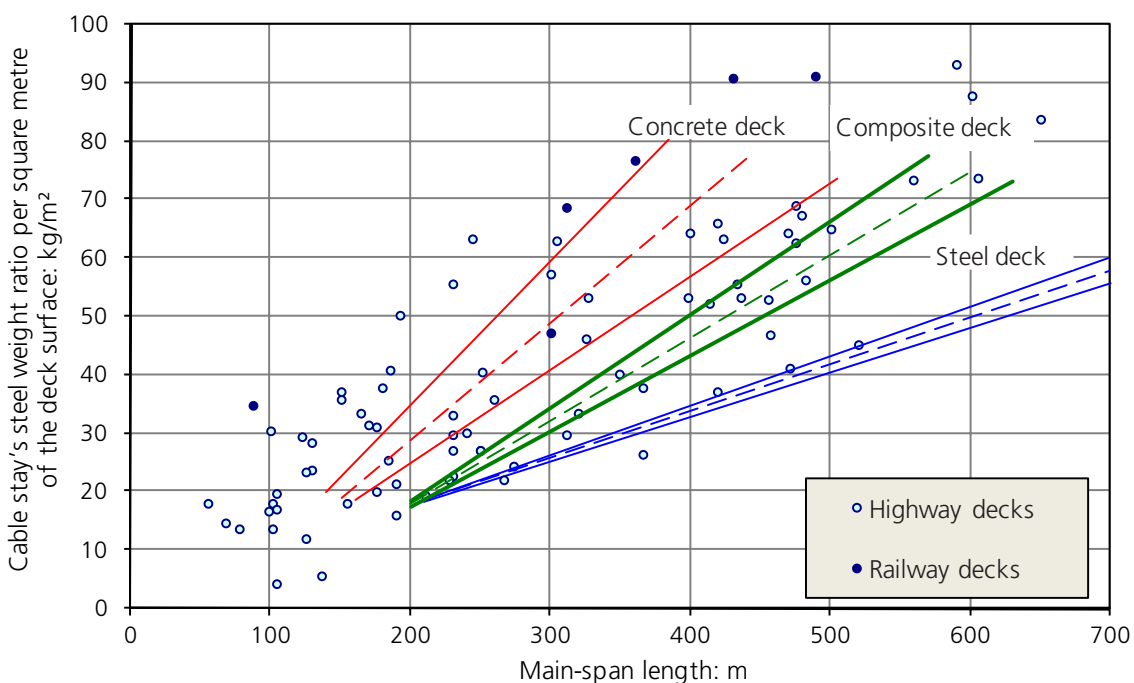

(a)

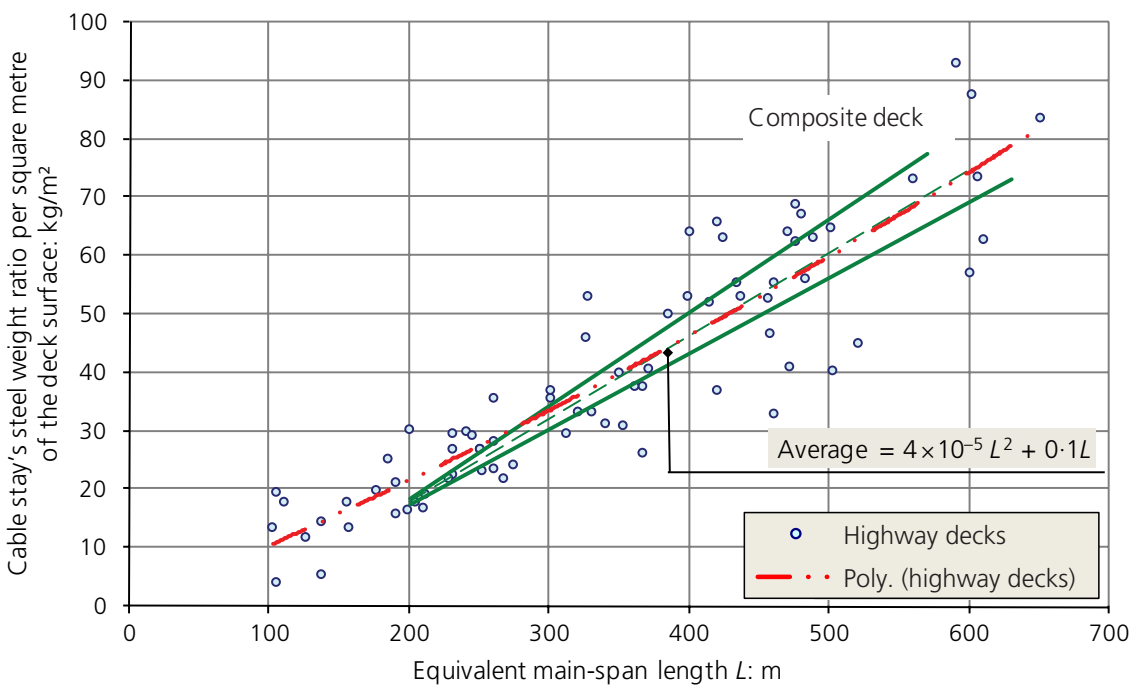

(b)

Figure 13. Cable steel weight ratio per square metre of the deck for composite cable-stayed bridges, against (a) main-span length; (b) equivalent main-span length

and welded. Later the stays were installed and temporary supports were removed to new positions (Sörensen and Thorsen, 1999).

The $360 \mathrm{~m}$ long span Mercosur railway bridge (Humpf and Schiele, 2009) under construction, also adopted a composite steel-concrete Warren truss girder deck, with $10 \mathrm{~m}$ between truss joints and upper and lower cross-girders $3.33 \mathrm{~m}$ apart. Unlike the other examples, central suspension was adopted. Side spans were erected by incremental launching, with the concrete slab cast in place afterwards, and stays installed and tensioned. The $120 \mathrm{~m}$ steel central part of the main span, weighing $2400 \mathrm{t}$, will be lifted from a barge by four strand jacks located on the existing cantilevers. The main span slab will finally be poured in several steps.

These two decks are relatively deep, with steel structures $10.2 \mathrm{~m}$ and $11.6 \mathrm{~m}$ high, which correspond to slenderness ratios of only 48 and 28 (Figure 11). In addition, the selfweight and structural steel quantity of these decks are higher than the values for double plate girder composite decks (Figure 12). 


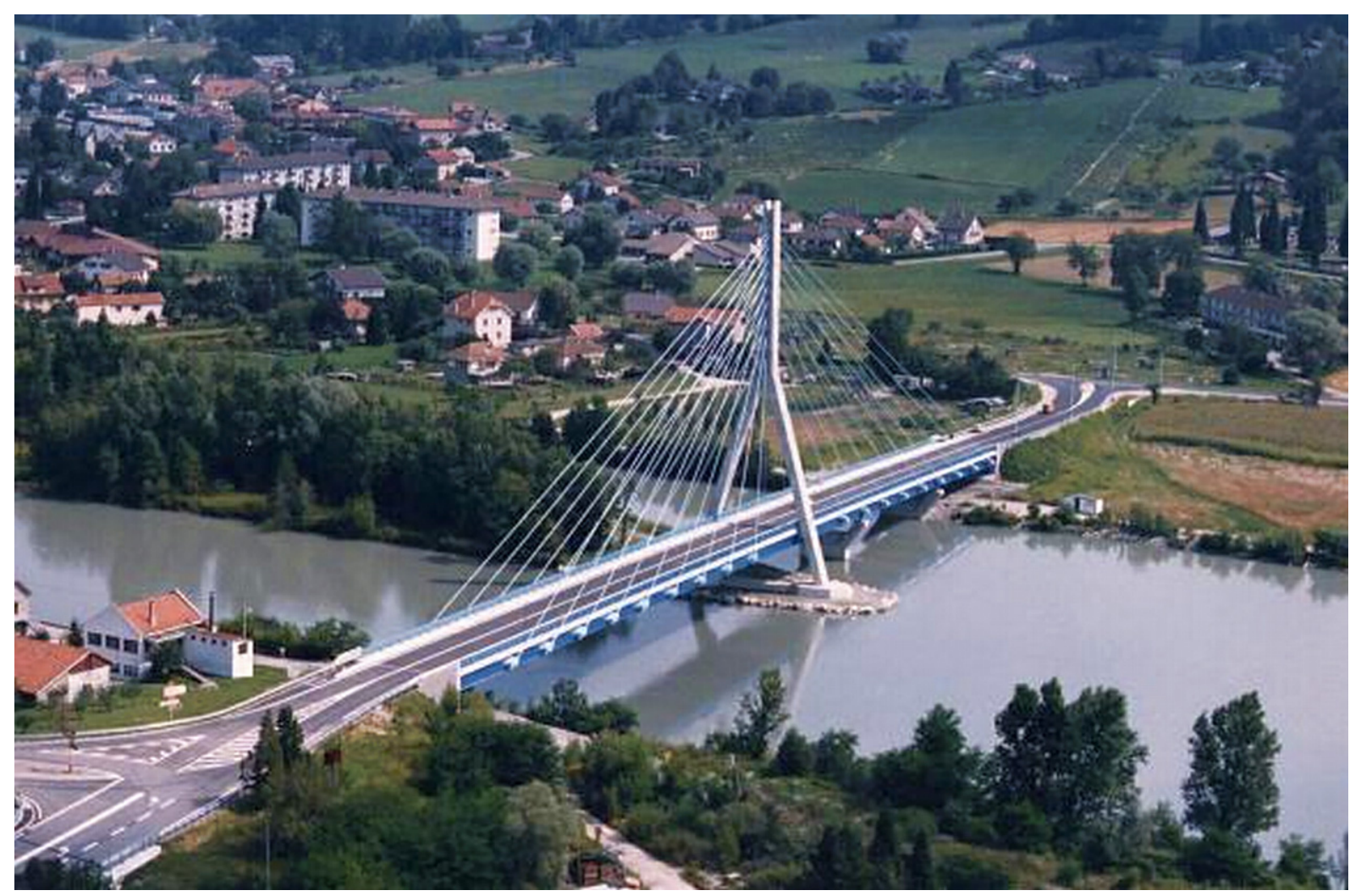

(a)

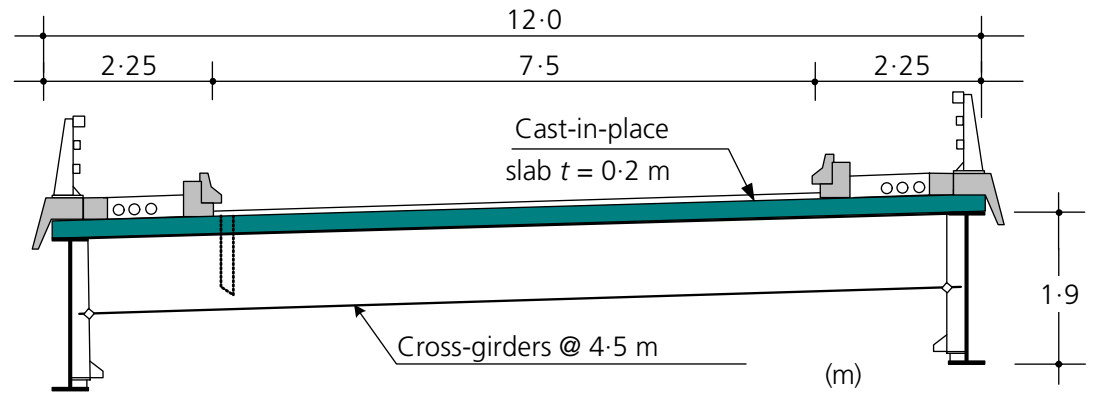

(b)

Figure 14. (a) Seyssel Bridge, France (1987) (Courtesy of SETRA, photograph by Gérard Forquet); (b) deck cross-section

Traditionally, composite cable-stayed truss decks adopted vertical diagonals. However, 3D tubular diagonals can also be used, as was first done in the Europa Bridge over the Mondego River in Portugal (2004; Figure 19) (Reis and Pedro, 2004). This highway deck, with a $186 \mathrm{~m}$ long main span, is centrally suspended by two planes of stays fixed to a single mast located on the left bank of the river. The mast, inclined $8^{\circ}$ towards the side spans, is restrained by backstays externally anchored to the transition pier blocks. The deck is a $3 \mathrm{D}$ composite truss, $4 \cdot 2 \mathrm{~m}$ deep and $30 \mathrm{~m}$ wide, made of high-strength steel tubes with joints spaced at $3.75 \mathrm{~m}$, and two concrete slabs prestressed in the transverse and longitudinal directions.

The specific characteristic of this composite deck truss also comes from the diagonal joints to the concrete slabs. Steel plates enclosed by reinforced concrete were used at the upper truss nodes. These plates not only transfer the vertical forces from the slabs but also balance the forces between the diagonal tubes that converge on the node, and transmit the horizontal forces to the concrete slabs. On the lower node between 


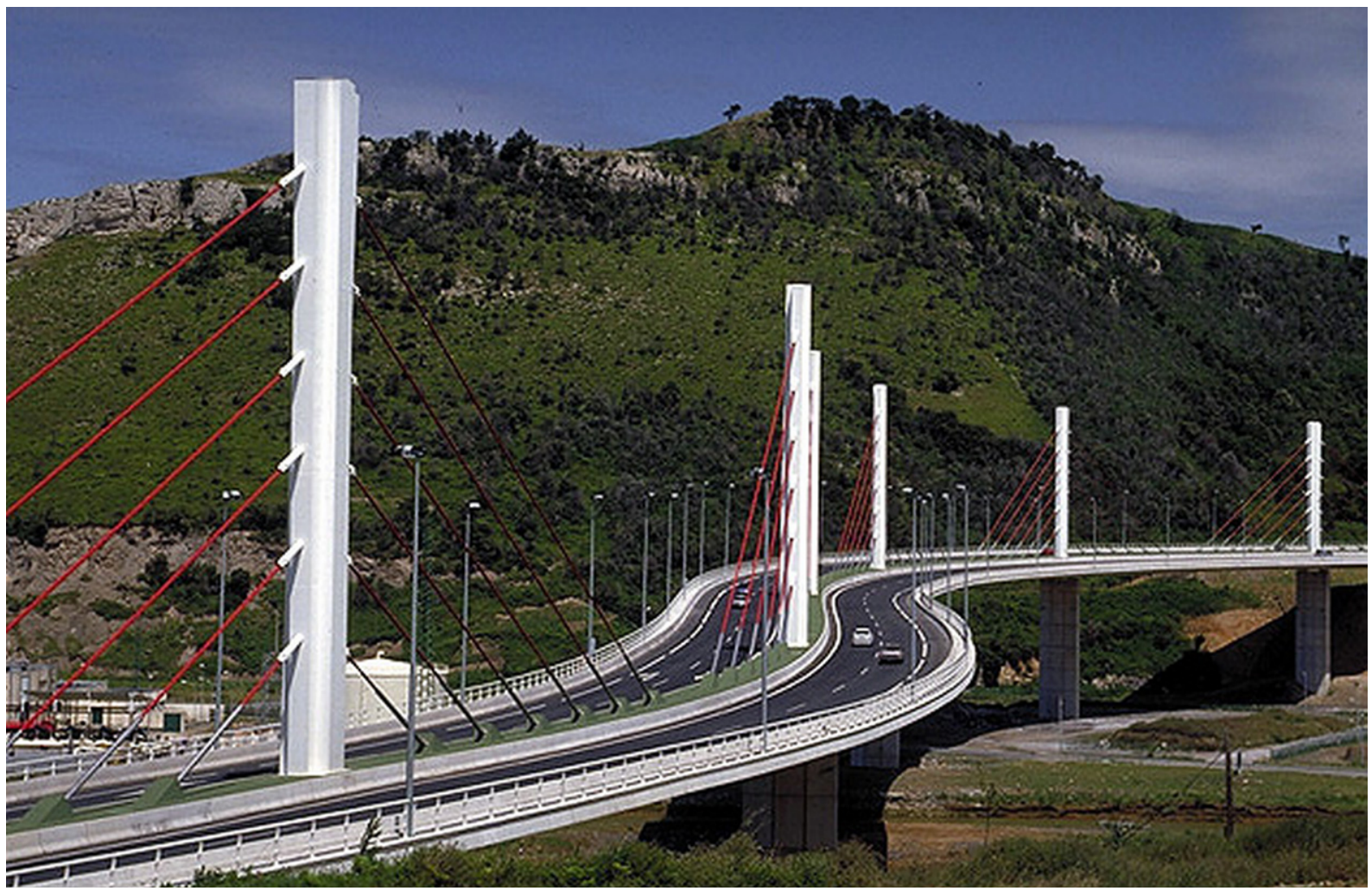

(a)

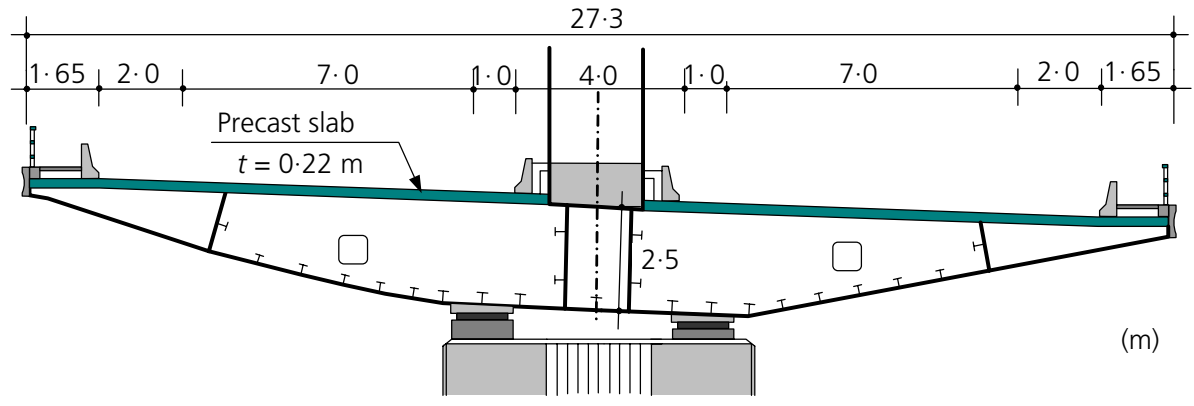

(b)

Figure 15. (a) Arena Viaduct, Spain (1993) (Courtesy of

Freyssinet); (b) deck cross-section

$3.75 \mathrm{~m}$ long segments, two 'teeth' plates were used, perfectly matched to each other, to ensure the direct transmission of vertical and horizontal internal forces. The bridge deck was designed to be erected using segments that were precast in the yard located on the left bank. Such segments $(3.75 \mathrm{~m}$ long and weighing up to $150 \mathrm{t}$ ) were transported by barge and then lifted to the deck. After deck erection and installation of the longitudinal prestressing, the deck slab cantilevers were cast in place and additional transverse prestressing was installed.

\section{Future trends}

The competitiveness of long-span composite cable-stayed bridges is first due to the fact that the cost of construction per square metre of deck does not show great sensitivity to the span increase and, second, to the fact that none of the bridge main parts - deck, piers/pylons, or stays - have reached their limit of application. Particularly adverse foundation conditions raise the competitiveness of long-span composite cable-stayed bridges. Future developments of composite cable-stayed 


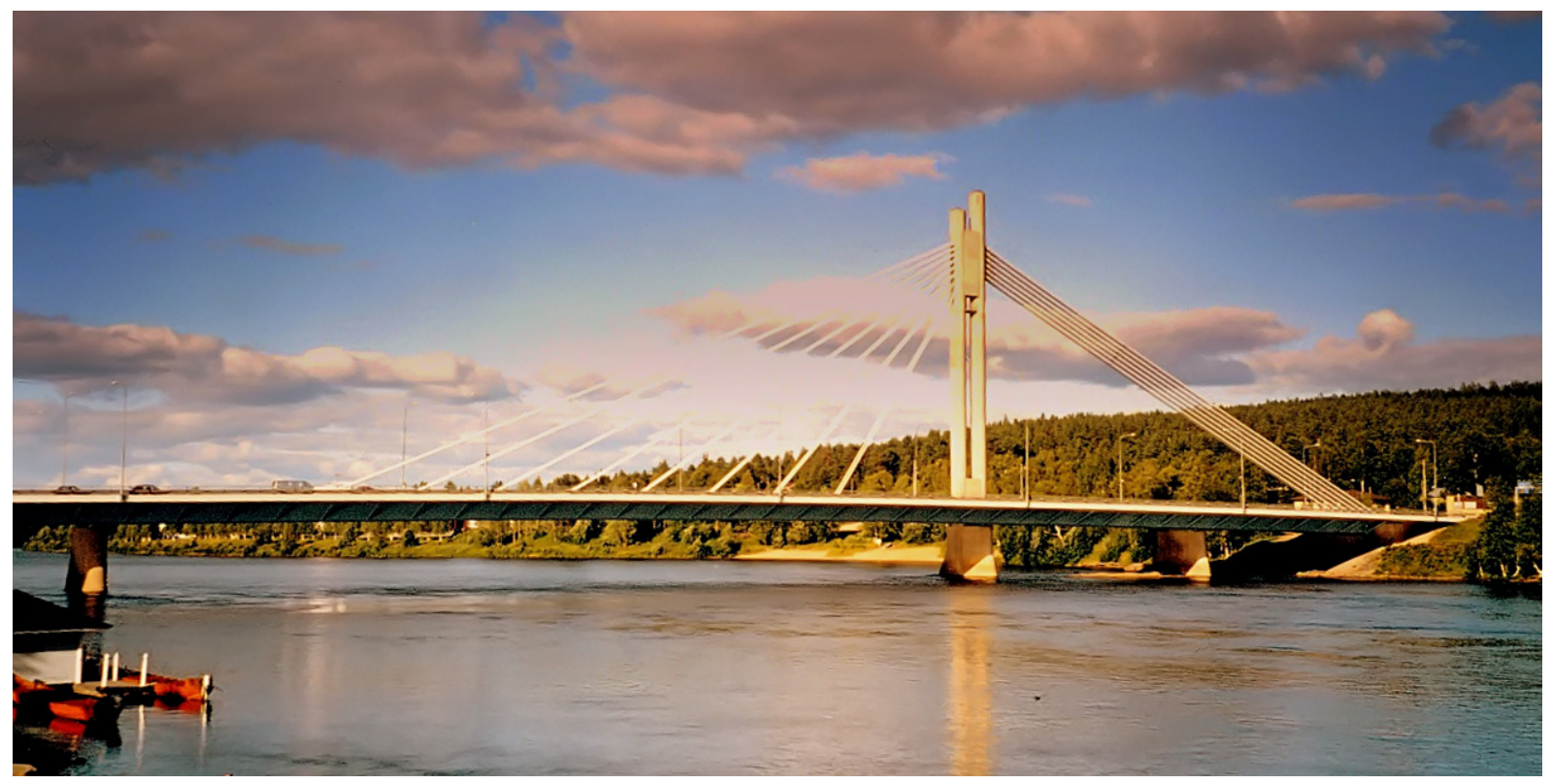

(a)

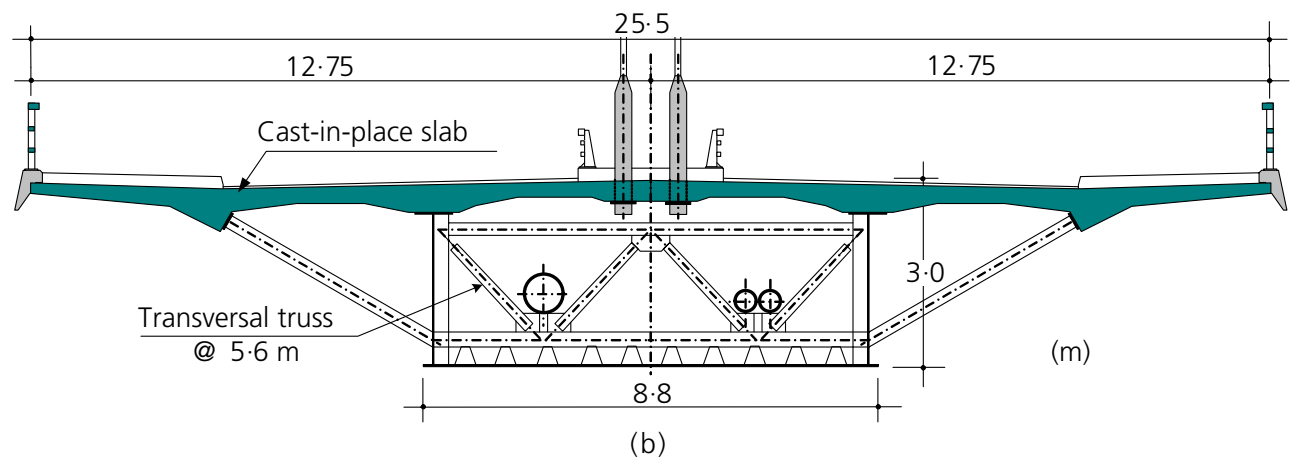

Figure 16. (a) Kemijoki Bridge, Finland (1989) (Photograph by

J. O. Pedro); (b) deck cross-section

bridges are due to improvements in the field of structural materials and stay cables, as well as in the field of design solutions.

\subsection{In the field of materials}

The use of precast deck slab panels with concrete strengths up to $70-100 \mathrm{MPa}$ is gradually increasing for very long span composite cable-stayed bridges. High-strength concrete enables the design of deck slabs with thicknesses around $0 \cdot 2-0 \cdot 25 \mathrm{~m}$, with the capacity to resist the horizontal compression forces corresponding to spans of about $700-800 \mathrm{~m}$. To reduce weight, ribbed slab sections between cross-girders, as recently adopted, seem to be a good solution for deck sections not near to the pylons. Lightweight aggregate concrete was also used in at least one composite cable-stayed deck. The Grenland Bridge, Norway (1996) adopted slabs of lightweight aggregate concrete in the $305 \mathrm{~m}$ long main span. Comparative calculations of costs of this option have shown that it led to a $1 \%$ reduction in the total cost of the bridge (Fergestad and Jordet, 2000). These savings were due to the decrease in the deck self-weight and therefore also of the stay cable steel weight and bridge foundations. Even if the concrete made with lightweight aggregates is more expensive than normal, in future designs the savings from the lower weight of the deck can pay off.

The use of steel grades S420 and S460 has increased in recent years, replacing steel grade S355 that was common previously. New steels allow the design of steel girders, cross-girders and especially stay anchors to be more compact with thinner plates. However, the use of these steels has no significant advantage for fatigue resistance, and can increase the risk of buckling instability, requiring additional stiffeners. Therefore, the 


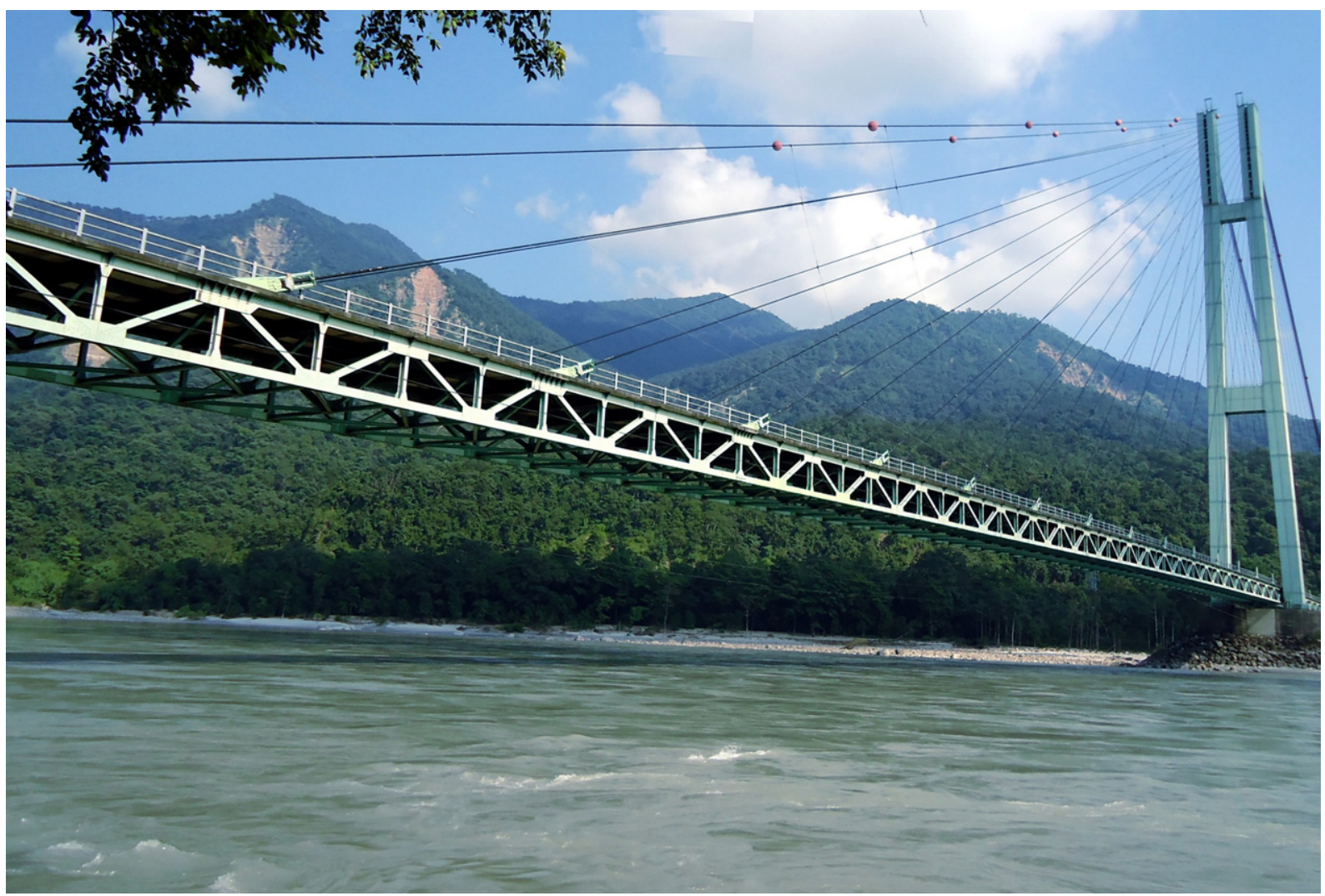

(a)

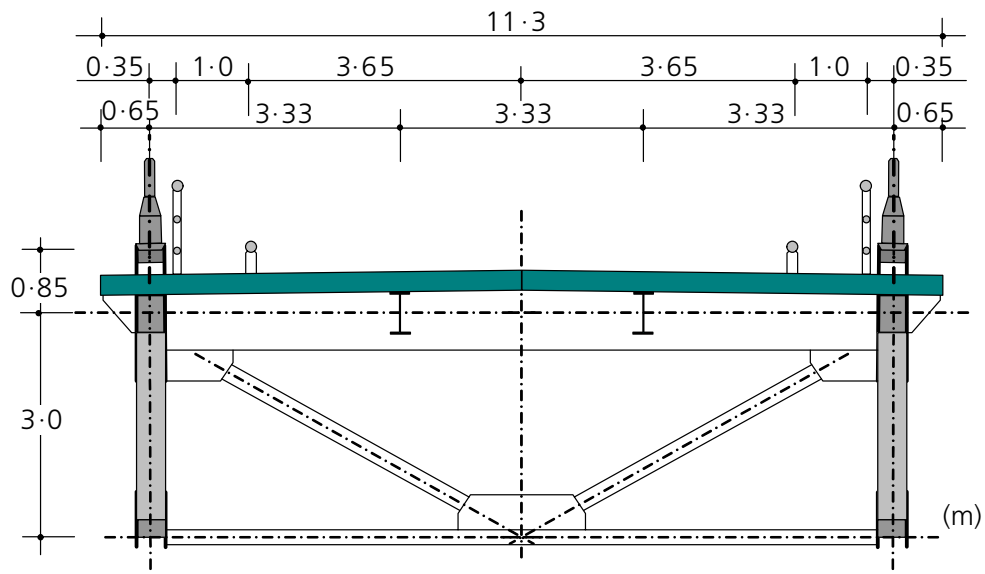

(b)

Figure 17. (a) Karnali Bridge, Nepal (1993) (Courtesy Anunoy

Samanta); (b) deck cross-section

ultimate overall balance of steel cost savings is an issue to be analysed in each design. The recent introduction of even higher steel grades in bridge construction, such as S690 and S700, may be explored in the future (IABSE, 2005). This solution creates a new set of research topics, namely in the field of stability and fatigue issues.

\subsection{In the field of cables}

The increase of cable-stayed bridge spans has led to longer stay cables, with relatively reduced cable stiffness. Cables made of carbon and aramid fibre reinforced polymers have been proposed to reduce weight and diameter, as they combine very high resistance with lower self-weight than steel. However, 


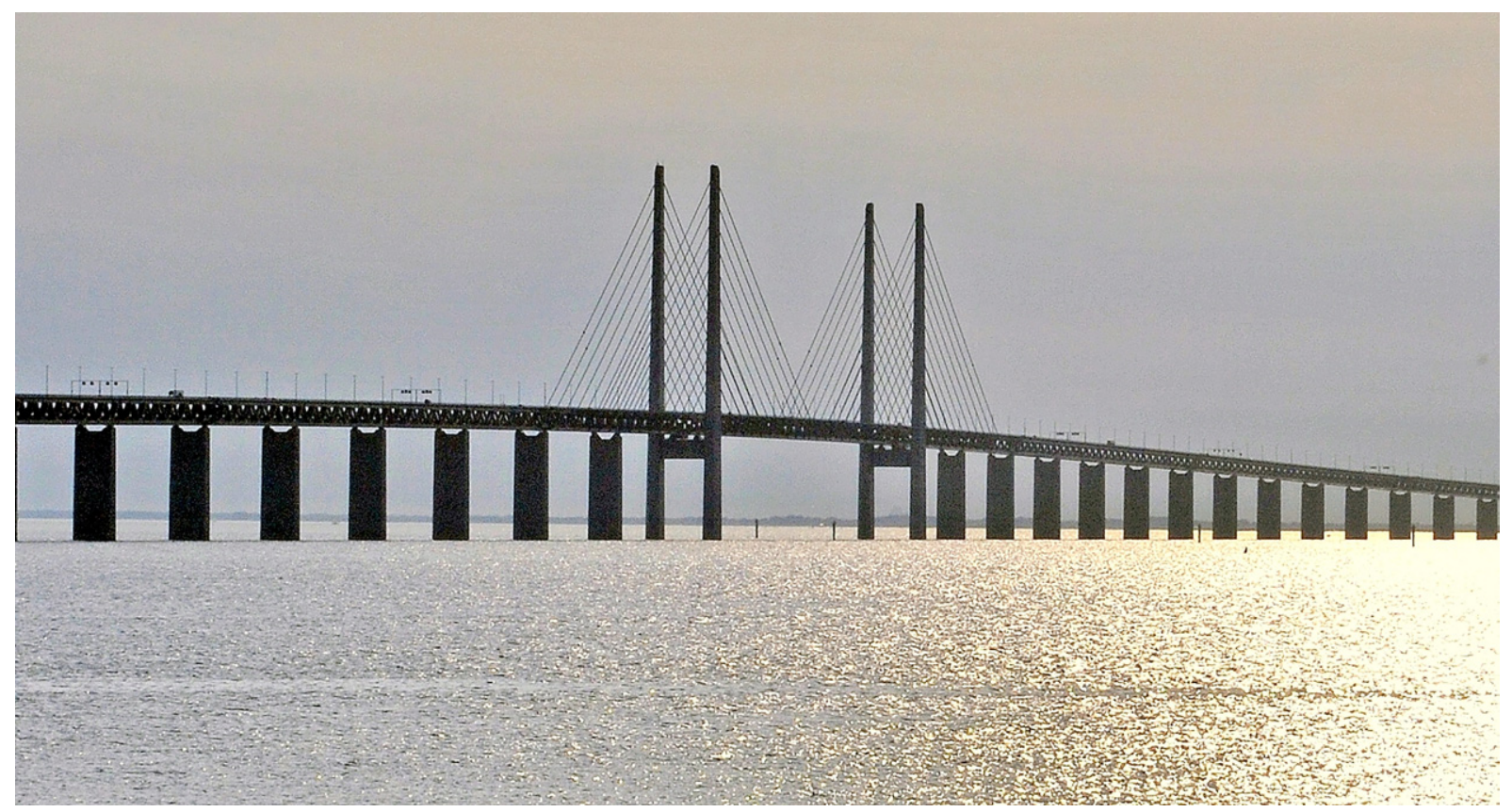

(a)

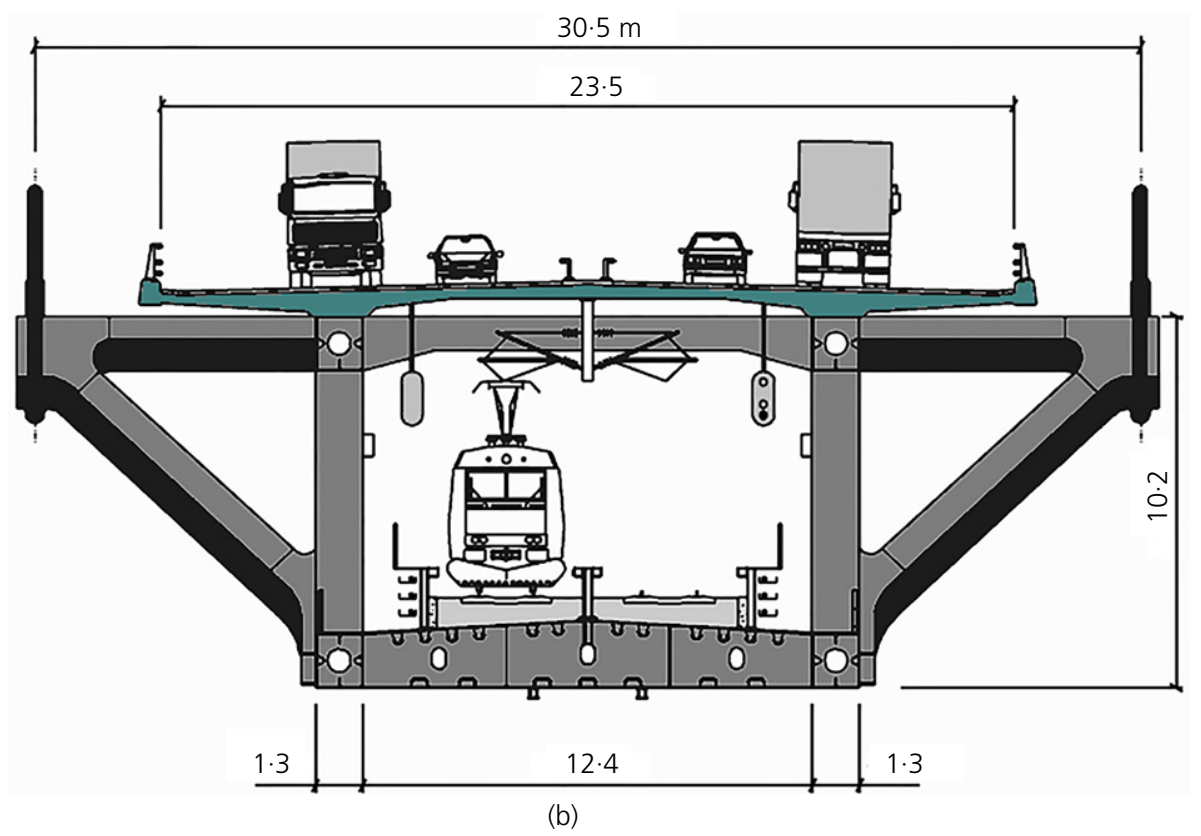

Figure 18. (a) Øresund Bridge, Sweden/Denmark (2000)

(Photograph by Soerfm); (b) deck cross-section

uncertainty about their ability to carry significant loads for a long period of time, higher deformability and especially higher cost compared to steel, have restricted composite stays to some pedestrian crossings and experimental tests on small highway bridges.
Over the years, conventional steel cables have seen progressive improvements. The classic prestressing strands individually protected and surrounded by cement grout inside a plastic tube are a weighty solution and have a large outer diameter, and it is impossible to replace strands one by 


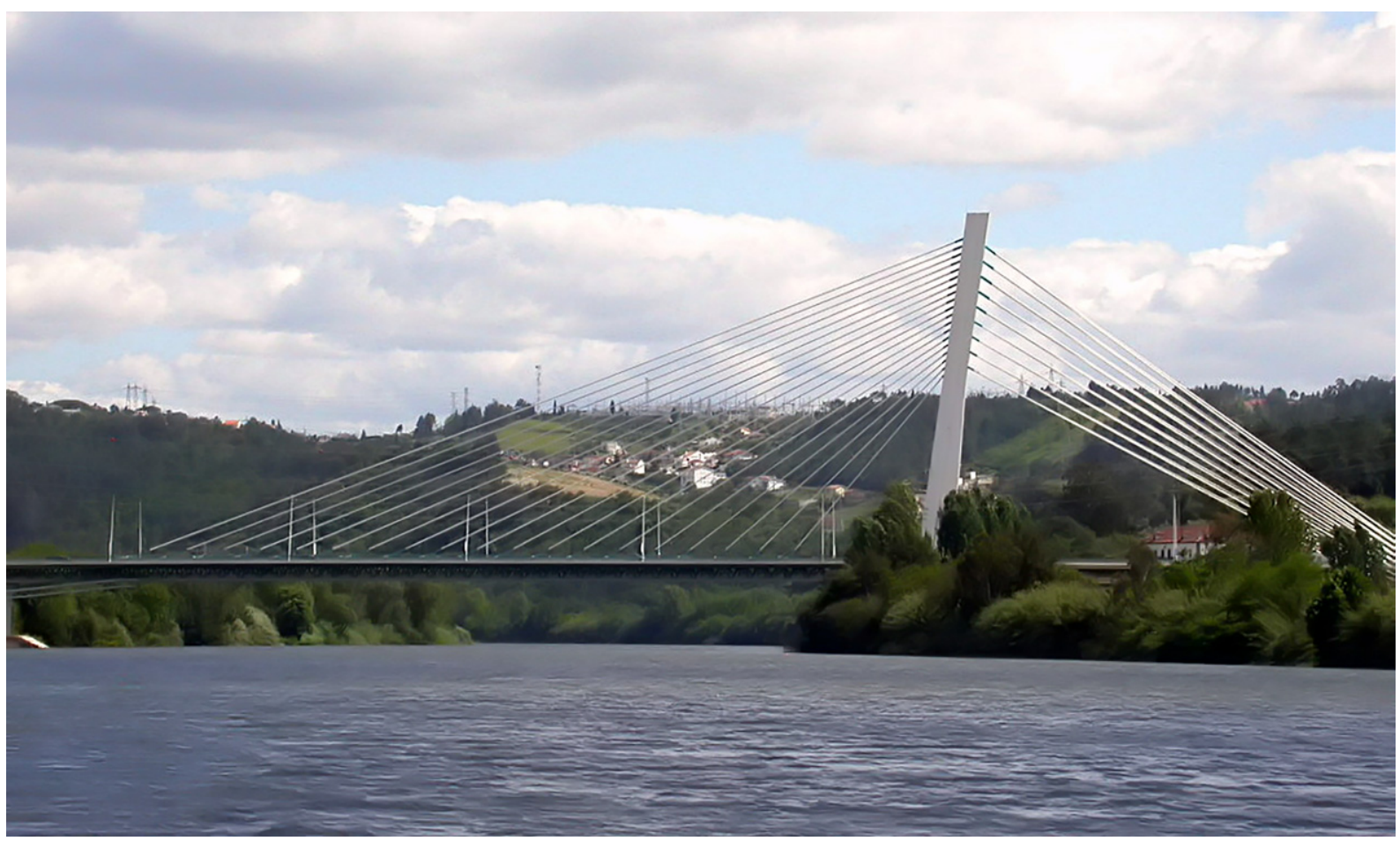

(a)

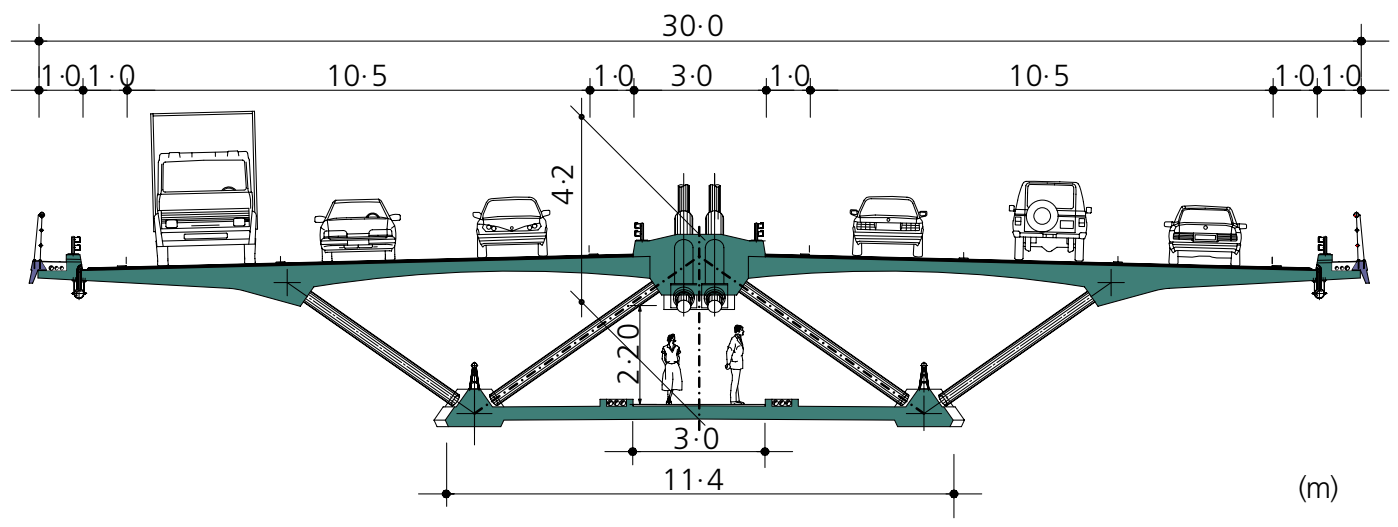

(b)

Figure 19. (a) Europa Bridge, Portugal (2004) (Photograph by

J. O. Pedro); (b) deck cross-section

one. These disadvantages led to the substitution of cement grout by synthetic materials such as wax or resin, which increases protection and reduces the weight and diameter of the cable.

Also in the anchorages of the cable, important developments have occurred, notably in the design of devices that increase the damping of cable vibration and allow reduction in the local cables, bending stresses induced by anchorages.
Cable forces in service are usually limited to $45 \%$ of the guaranteed ultimate tensile strength $\left(\mathrm{F}_{\mathrm{GUT}}\right)$. Few solid justifications have been given to continue using this limit, imposed to prevent the negative consequences of the fatigue stresses and local bending stresses in the anchorage of the first largediameter stay cables. For a characteristic combination of loads, part 1.11 of Eurocode 3 (CEN, 2006a) allows cable forces up to $50 \%$ of $\mathrm{F}_{\mathrm{GUT}}$, providing vibration damping devices are adopted at anchorages and Eurocode 1 part 2 (CEN, 2003) 
actions are used. This higher limit is connected with the imposition of technological requirements for cables and anchorages, which bridges built in the past $10-15$ years have generally adopted. In addition, during cable installation, the first strands may have installed forces up to $60 \% \mathrm{~F}_{\mathrm{GUT}}$, provided after stressing the remaining strands of a cable work in the limit of $55 \% \mathrm{~F}_{\mathrm{GUT}}$.

Some countries have developed recommendations and specific codes for the design of stay cables, such as the documents published in 2001 in France and the USA (PTI, 2001; SETRA, 2001), but also part 1-11 of Eurocode 3 (CEN, 2006a). These codes define the cable safety verification for the ultimate limit state, as well as stress limits in service conditions, which in general govern design.

The fatigue verifications for the cable stays are also to be carried out (considering both the axial stresses and the bending stresses near the anchorages, due to angular deviations caused by catenary effects, wind forces and erection imperfections). The French recommendations propose a simple form valid for highway bridges, limiting the cable axial stress variation to $70 \mathrm{MPa}$ for the passage of the fatigue vehicle LM3 of EC1-2. Eurocode 3 (CEN, 2005, 2006a, 2006b) contains a more complex verification procedure. Design practice has shown fatigue often governs the design of stay cables, thus justifying further research for evaluating to what extent fatigue is important and obtaining simplified procedures for its verification.

\subsection{In the field of design}

In the field of the design of composite steel-concrete cable-stayed bridges, several new solutions have been recorded over the years, in some cases only with architectural aspects, but in other cases these were technically innovative. Both types of developments are important, because the public interest in cable-stayed bridges is, to a large extent, also a result of their high aesthetic quality. In fact, good aesthetics and landscaping, and a great capacity to solve local site constraints that require the introduction of longer spans in highly sensitive environmental areas, are factors contributing to the adoption of cable-stayed bridges with different composite deck solutions and singular stay and mast configurations.

The recent Boyne and Suir River bridges in Ireland (2003 and 2009), Sirhowy River Bridge, Wales (2005), Berliner Bridge, Germany (2005), Alcide de Gasperi Bridge in Italy (2005) and Korabelny Bridge, Russia (2011) are good examples of medium-span composite cable-stayed bridges following these principles. New bridges of the same type, such as the Signature Bridge in India (2014), are being constructed or designed. The structural possibilities in this domain provide solutions that challenge the classic three-span design erected by the standard cantilever construction method. Asymmetric spans with a single pylon and special stay arrangements, or partially earth anchored cable-stayed systems, will be adopted with mediumspan composite decks.

Cable-stayed bridges with longitudinal plate girders and box girder decks will become more slender and streamlined for spans longer than $700 \mathrm{~m}$ in order to reduce lateral wind sensitivity. Due to wind lateral forces, structurally separated decks also have advantages in lateral bending behaviour, providing that the full effective girder width is achieved by transverse framing capable of mobilising full-depth lateral bending action. In this respect, Stonecutters Bridge, with a $1018 \mathrm{~m}$ long main span located in potentially very high velocity winds, has a deck split into two longitudinal components, structurally connected for Vierendeel action, as was done before in the Ting Kau Bridge. Although the constructed solution adopted a twin orthotropic steel box girder deck, an evaluation of a composite deck solution was done with a ribbed concrete slab, with a strength of $60 \mathrm{MPa}$ and an average thickness of $244 \mathrm{~mm}$, spanning $3.75 \mathrm{~m}$ between cross-girders (Taylor, 2001). However, for the regions within $50 \mathrm{~m}$ from the pylons, it was necessary to increase the slab thickness to $300 \mathrm{~mm}$ to handle the combined effects of lateral bending moments under lateral wind combined with coexistent axial load. Even so, the $25 \mathrm{MPa}$ tension due to lateral bending exceeded to a large extent the $15 \mathrm{MPa}$ compression due to axial load, which implied a tension demand in the concrete slab in excess of the cracking strength. With this assessment, it became clear that the combined effects of lateral wind bending on the deck and axial loads is a governing criterion when composite deck spans reach about $1000 \mathrm{~m}$ long (Taylor, 2001). On this bridge, the concrete side spans have only $30 \%$ of the length of the main span, which increase vertical and in-plan deck stiffness, essential for stabilising the main span during construction.

The same concept was used in Istanbul's Third Bosphorus Bridge, presently under construction. With an all-steel main span deck of $1408 \mathrm{~m}$, the central part is suspended from suspension cables and the rest is cable stayed, including the $300 \mathrm{~m}$ long concrete side spans. This bridge revived the design concept of a hybrid cable-stayed/suspension bridge, with the main suspension cable externally anchored. Although this design is rather unusual, it will possibly be used with a composite deck in the future.

Important developments are also expected in cable-stayed bridges with multiple spans. The Rion-Antirion Bridge adopted three consecutive $560 \mathrm{~m}$ long spans, with a flexible composite deck, but very stiff pylons, with considerable visual impact. This design has enormous potential, as the recent 


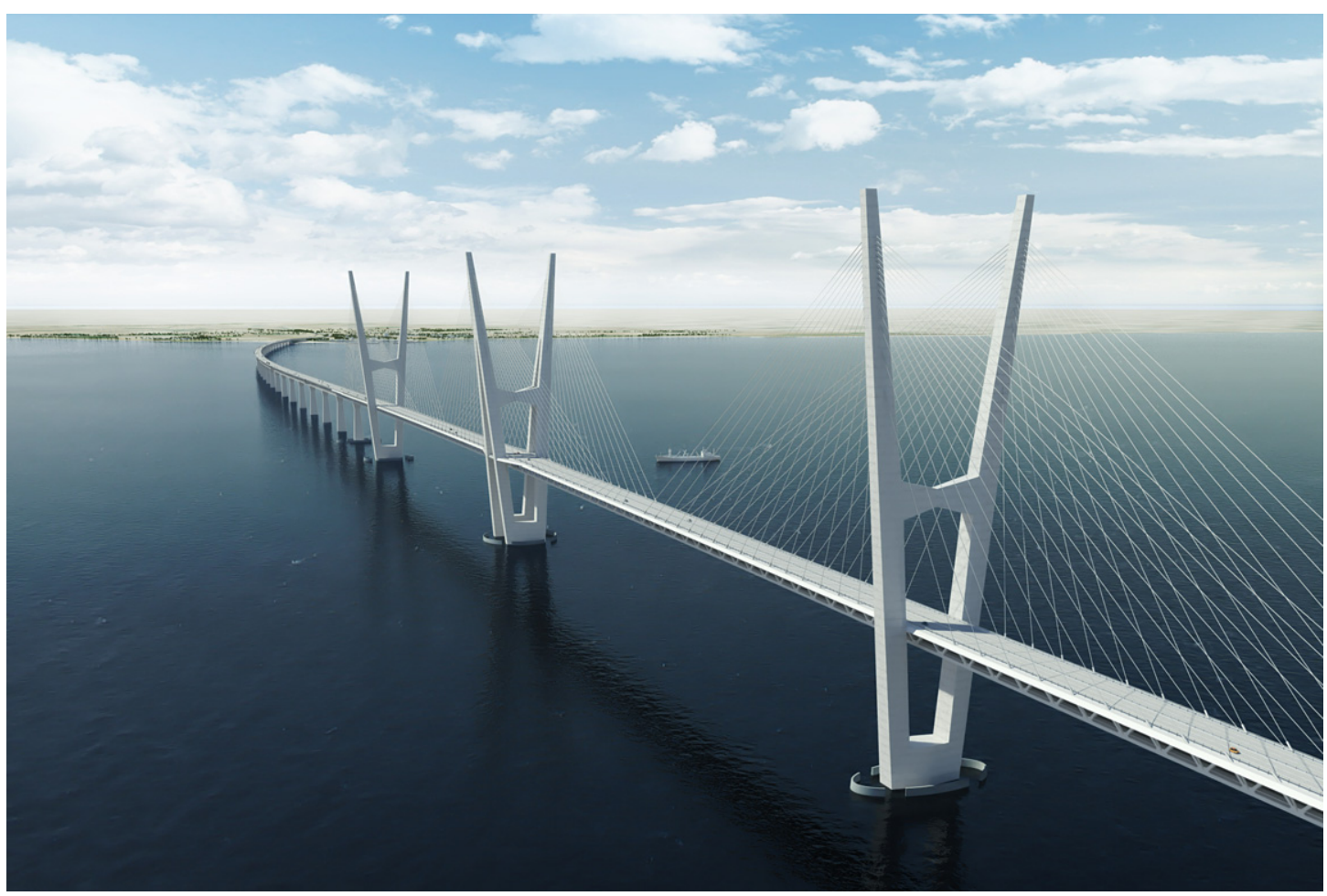

(a)

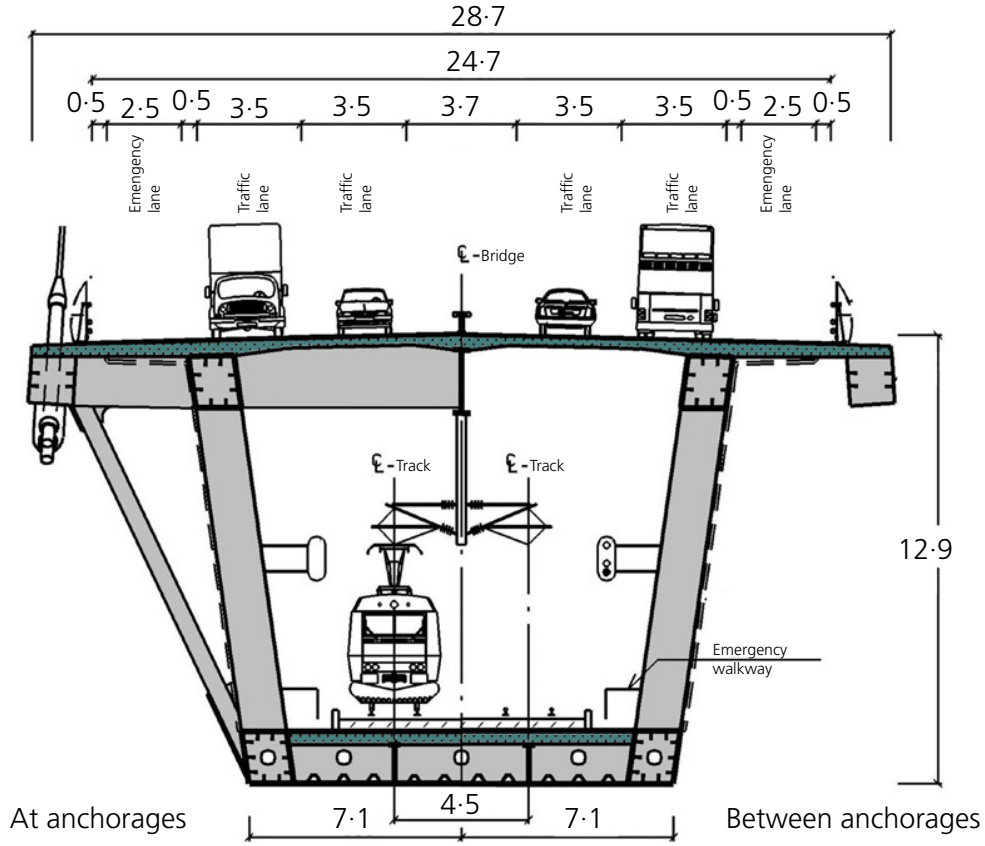

(b)

Figure 20. (a) Preview of the Fehmarn Belt Bridge solution, between Germany and Denmark (Courtesy of Jens Villemoes/ Femern A/S); (b) deck cross-section 


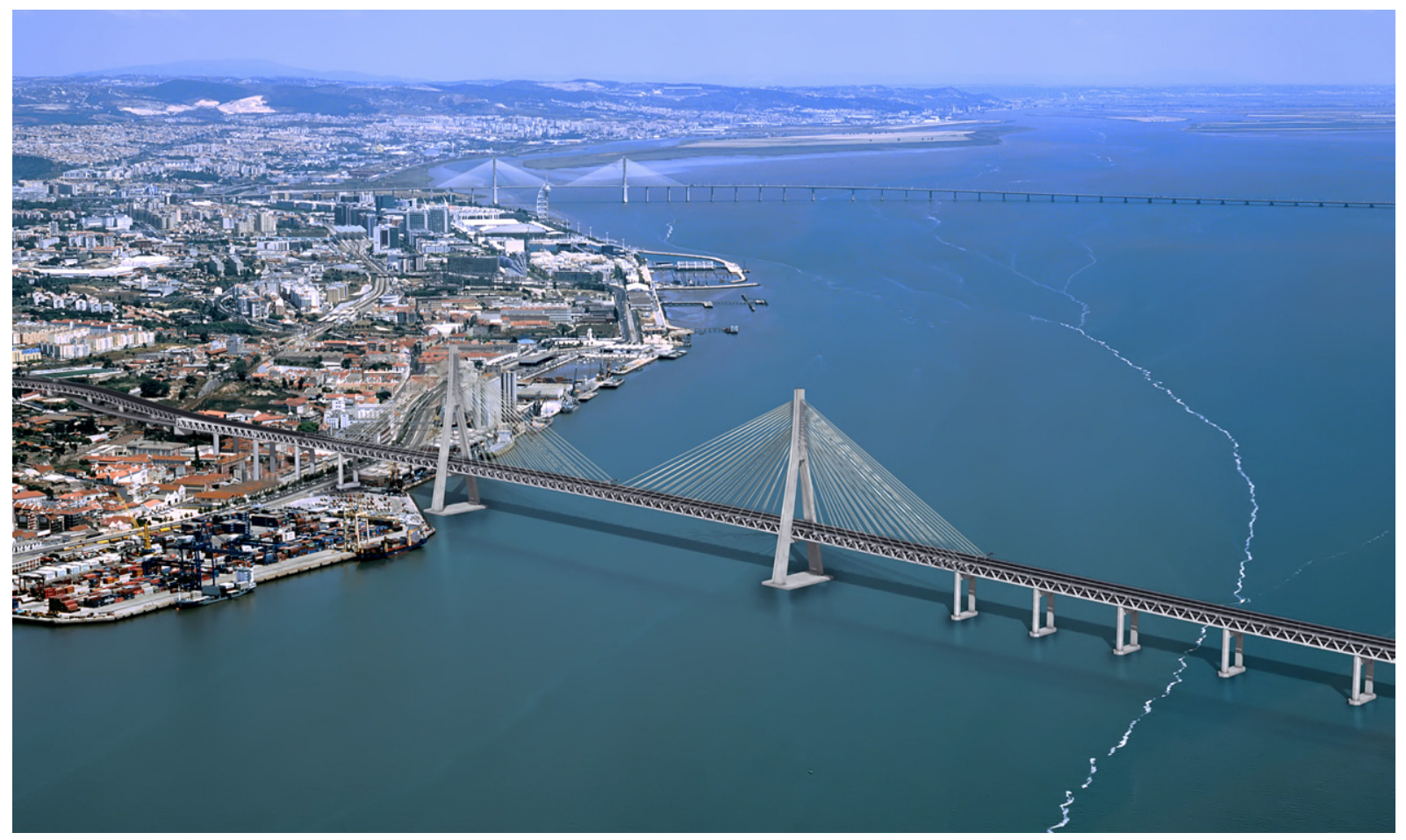

(a)

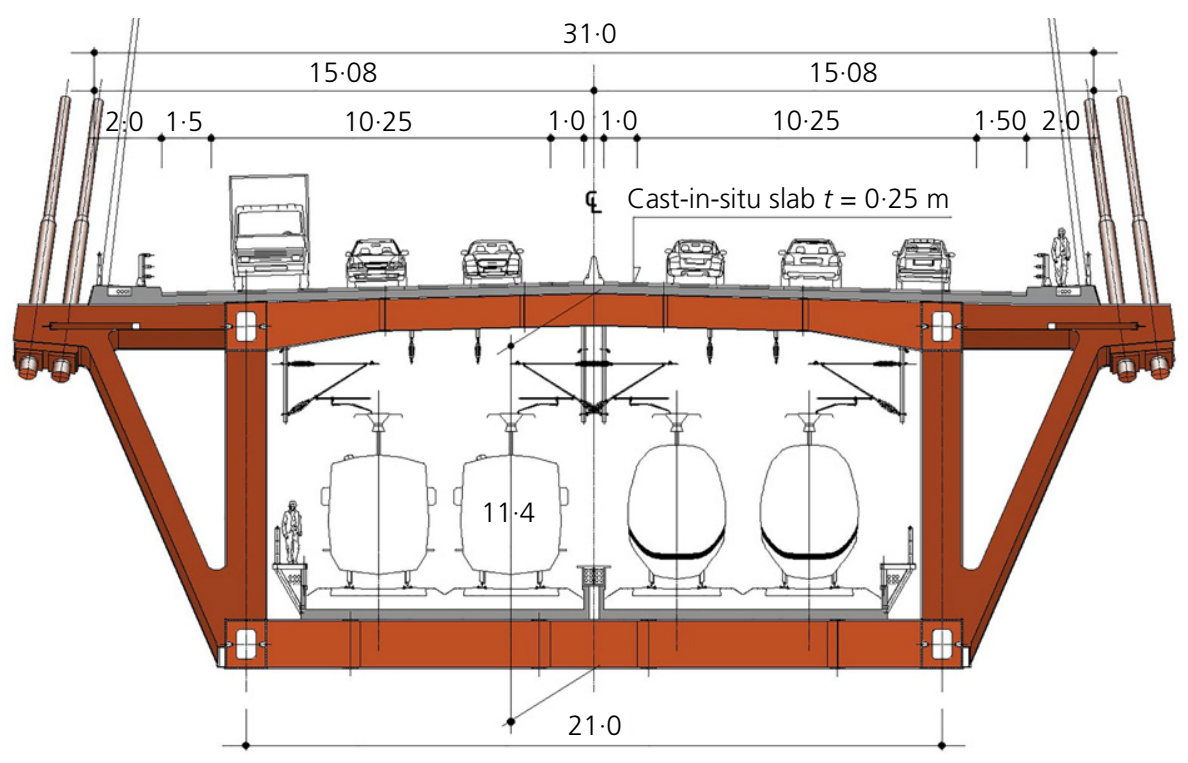

(b)

Figure 21. (a) Preview of the Third Tagus River Crossing Bridge in Lisbon (courtesy of GRID Consulting Engineers); (b) deck crosssection

Queensferry Crossing Bridge and Fehmarn Belt Bridge confirm, because it allows distances of several kilometres to be overcome without the need for exceptionally long spans.
In the field of railway decks, composite solutions can also play an important role. These bridges require stiffer decks, sometimes with aerodynamic problems when the deck has a small 
width. Hence, the concrete slab has some advantages, compared to orthotropic steel plates, of providing greater stiffness to the deck and the adequate road platform. In the near future, this is certainly an area of composite cable-stayed bridge development, as shown by the recent studies for the Third Tagus River Crossing Bridge in Portugal (GRID, 2009; Reis, 2008), and for the bridge solution connecting the Fehmarn Belt between Germany and Denmark (Femern A/S, 2011).

For the Fehmarn Belt Bridge, a bridge deck with 724 m-long spans and a steel-concrete composite truss was first proposed (Figure 20), although an all-steel cross-section was then studied. Finally, the bridge solution was not retained as an immersed tunnel is being constructed. Trains run on the lower deck and cars on the upper deck. The deck is $12.9 \mathrm{~m}$ deep and $28.7 \mathrm{~m}$ wide, which corresponds to a slenderness ratio of 56 , similar to other railway composite truss cable-stayed decks.

A $7 \mathrm{~km}$ long double-deck bridge for rail and road traffic, including two high-speed lines and two conventional lines on the lower deck, was also proposed for the third crossing of the Tagus River in Lisbon (Figure 21), although this project is suspended for financial reasons. The main cable-stayed bridge, with a $540 \mathrm{~m}$ long main span, adopts a steel-concrete composite deck, with a Warren-type truss $11.4 \mathrm{~m}$ deep, suspended laterally by two planes of cable stays (with two cables in each 'plane').

The proposed deck will comprise two vertical truss girders, with steel chord and diagonal welded tubular sections in steel S460 N/NL. To anchor the stays at the upper deck level, crossgirders at $15 \mathrm{~m}$ spacing are to be extended from the chord axes, to anchor the stay cables. Tie bars with the same inclination of the diagonals will transfer the loads from the stay anchorages to the lower chords. The four stringers of the upper and lower decks will participate in the overall bending resistance of the deck cross-section, reducing the axial forces in the chord members but inducing in the cross-girders transverse bending moments. The concrete deck slab spanning between cross-girders and stringers will work compositely with the upper and lower steel framing. Although the main span length of the deck is usually the benchmark in bridge comparative analyses, the distinctive aspect of this bridge is the structural solutions proposed for a deck with four railway lines, which highlights this singular design in the field of cable-stayed railway bridges.

\section{Conclusion}

Composite cable-stayed bridges are a very competitive bridge solution when 400-600 m main spans are required. There has been a remarkable development in the past 25 years, predominantly for highway bridges with two longitudinal plate girders and closely spaced cross-girders supporting the deck reinforced concrete slab. In the future, this solution will certainly be extended to longer spans, using longitudinal plate girders or box girders with deck slabs of high-strength concrete. New designs are also expected in the domain of railway bridges, namely using composite truss decks, as they have already proved to be an efficient solution for long spans requiring stiffer decks.

\section{Acknowledgements}

The authors would like to thank all suppliers of the photographs used in the paper.

\section{REFERENCES}

Abrahams MJ (2005) Arthur J. Ravenel Jr. Bridge over Cooper River. National Steel Bridge Alliance Bridge Award, Modern Steel Construction. American Institute of Steel Construction, Chicago, IL, USA.

Arenas J and Pantaleón M (1992) 'Puentes mixtos atirantados', Puentes mixtos: Estado actual de su tecnología y análisis. Comunicaciones y Mesas Redondas de las Primeras Jornadas Internacionales, Barcelona, Spain (in Spanish). Arzoumanidis S and Kunihiro M (1994) The Carnali River Bridge. Proceedings of the International Conference AIPC-FIP, Deauville, France, pp. 395-404.

Aso (1999) The Øresund Bridge. Aso Group, Sweden, 39 pp. Bergermann R and Schlaich M (1998) The Ting Kau Bridge in Hong Kong. IABSE Symposium Report - Long-Span and High-Rise Structures. Kobe, Japan, pp. 409-414.

Biwer R, Hubert F, Cremer J-M and Ville de Goyet V (1994) Cable-stayed bridge upon Alzette (Luxembourg). Proceedings of an International Conference AIPC-FIP Proceedings, Deauville, France, vol. 1, pp. 413-420.

Carney C and Nowak D (2011) Forth Replacement Crossing construction proposals. Proceedings of IABSE Symposium - Taller, Longer, Lighter. London, UK, paper No. 0968.

CEN (2003) Eurocode 1: Actions on structures - Part 2: Traffic loads on bridges. CEN, Brussels, Belgium.

CEN (2005) Eurocode 3: Design of steel structures - Part 1.9: Fatigue. CEN, Brussels, Belgium.

CEN (2006a) Eurocode 3: Design of steel structures - Part 1.11: Design of structures with tension components. CEN, Brussels, Belgium.

CEN (2006b) Eurocode 3: Design of steel structures - Part 2: Steel bridges. CEN, Brussels, Belgium.

Combault J, Teyssandier JP, Haste ND et al. (1994) Second Severn Bridge. Proceedings of the XII FIP Congress. AFPC - La Technique Francais du Beton Precontraint, Washington, USA, pp. 359-371.

Curran P, Elnegaard J, Patch A, Bolton I and Goldie I (2011) Forth Replacement Crossing - tender design. Proceedings of IABSE Symposium - Taller, Longer, Lighter, London, UK, paper No. 0966. 
Farquhar DJ (2008) Cable stayed bridges. In ICE Manual of Bridge Engineering, 2nd edn. Thomas Telford, London, UK.

Femern A/S (2011) SundBaelt - Consolidated Technical Report. Femern A/S, Copenhagen, Denmark. See www.femern. com/material-folder/documents/2011-publications/ consolidated-technical-report (accessed 04/06/2013).

Fergestad S and Jordet E (2000) The economic potential of LWAC in four different major bridges. Proceedings of the 2nd International Symposium on Structural Lightweight Aggregate Concrete, Kristiansand, Norway, pp. 355-364.

Freyssinet (1994) Cable-Stayed Bridges. Freyssinet International, Santes, France.

Freyssinet (2004) Cable-Stayed Structures. Freyssinet International, Santes, France.

GRID (2009) Third Tagus River Crossing: Main BridgeBase Case Design. GRID SA, Lisbon, Portugal (in Portuguese).

Hague ST (2003) Steel/concrete composite design for long span bridges. Proceedings of Transportation Research Board 2003 Annual Meeting, Washington, DC, USA.

Humpf K and Schiele I (2009) Puente Mercosur - Truss Girder Bridge across the Orinoco. Proceedings of the IABSE Conference, Bangkok, Thailand.

IABSE (International Association for Bridge and Structural Engineering) (2005) Use and Application of HighPerformance Steels for Steel Structures. IABSE Structural Engineering Documents No. 8, p. 152.

Leonhardt F and Zellner W (1991) Past, present and future of cable-stayed bridges. In Cable-Stayed Bridges, Recent Developments and their Future - Proceedings of the Seminar, Yokohama, Japan, 10-11 December 1991 (Developments in Civil Engineering) (Ito M, Fujino Y, Miyata T and Narita N (eds)). Elsevier, Amsterdam, the Netherlands.

Pedro JJO (2007) Structural Analysis of Composite CableStayed Bridges. PhD thesis, Technical University of Lisbon, Portugal, 426 pp (in Portuguese).

Pedro JJO and Reis AJ (2013) Composite steel-concrete cable-stayed bridges - Developments and future trends. Proceedings of the 5th International Conference on Structural Engineering, Mechanics and Computation, Cape Town, South Africa.

Podolny W and Scalzi J (1976) Construction and Design of Cable-Stayed Bridges, 1st edn. Wiley, New York, USA.

PTI (2001) PTI Guide Specification. Recommendations for Stay Cable Design, Testing and Installation, 4th edn. Post-Tensioning Institute, Farmington Hills, MI, USA. Reis AJ (2008) Composite bridges: options and design issues. Proceedings of the 7th International Conference on Steel Bridges, Guimarães, Portugal, pp. I-3-I-28.
Reis A and Pedro JJO (2004) The Europe bridge in Portugal: concept and structural design. Journal of Constructional Steel Research 60(3-5): 363-372.

Reis A, Pereira A, Pedro JO and Sousa D (1999) Cable-stayed bridges for urban spaces. Proceedings of the IABSE Conference - Cable-Stayed Bridges: Past, Present and Future, Malmö, Sweden, pp. 106-115.

SETRA (2001) Haubans. Recommandations de la commission interministérielle de la précontrainte. Ministère de l'Équipement des Transports et du Logement, SETRA, Paris, France, 198 pp. (in French).

Sörensen LT and Thorsen NE (1999) The Øresund Bridge, erection of the cable-stayed span. Proceedings of the IABSE Conference - Cable-Stayed Bridges: Past, Present and Future, Malmö, Sweden, pp. 465-475.

Svensson H (1999) The development of composite cable-stayed bridges. Proceedings of the IABSE Conference - CableStayed Bridges: Past, Present and Future, Malmö, Sweden, pp. 352-361.

Svensson H (2012) Cable-Stayed Bridges: 40 Years of Experience Worldwide, 1st edn. Ernst \& Sohn, Berlin, Germany.

Svensson HS, Cristopher BG and Saul R (1986) Design of a cable-stayed composite bridge. ASCE-Journal of Structural Engineering 112(3): 489-504.

Svensson HS and Lovett TG (1994) The twin cable-stayed Baytown bridge. Proceedings of an International Conference for AIPC FIP, Deauville, France, Deauville, France, vol. 1, pp. 361-368.

Tang MC (1994) Cable-stayed bridges in the United States. Proceedings of an International Conference AIPC-FIP, Deauville, France, vol. 1, pp. 213-224.

Taylor P (1994) Composite cable-stayed bridges. Proceedings of an International Conference AIPC-FIP, Deauville, France, vol. 1, pp. 185-198.

Taylor P (2001) What are the limiting criteria governing the maximum span of composite cable-stayed bridges? Proceedings of the 3rd International Meeting on Composite Bridges - State of the Art in Technology and Analysis, Madrid, Spain, pp. 43-54.

Taylor P and Torrejon J (1987) Annacis Bridge. Concrete International 9(7): 13-22.

Teyssandier J-P (1997) The Rion-Antirion Bridge. Proceedings of the FIP International Conference, Lisbon, Portugal, vol. 2, pp. 1163-1170.

Troitsky MS (1988) Cable-Stayed Bridges, 2nd edn. BSP Professional Books, Oxford, UK.

Vähäaho J, Järvenpää E and Pulkkinen P (1996) The cablestayed bridges in the Finnish lake and river landscape. Proceedings of the IABSE 15th Congress Report, Copenhagen, Denmark, pp. 171-177.

Virlogeux M (1990) Medium-span cable-stayed bridges. European Days in Civil Engineering at ENPC, Paris, France. 
Virlogeux M (2002) Les ponts à haubans. L'efficacité technique alliée à l'élégance architecturale. Bulletin Ponts Métalliques 21: 10-50 (in French).

Virlogeux M, Lacoste G, Mazou J et al. (1985) Projet et Construction du Pont de Seyssel. Bulletin Ponts Métalliques 12: 73-96 (in French).

Virola J (2013) El Puente Baluarte - High Cable-Stayed Bridge in Mexico. See http://koti.kontu.la/jvirola/acem-baluarte.pdf (accessed 09/2013).
Walther R, Houriet B, Isler W and Moia P (1985) Ponts

Haubanés. Presses Polytechniques Romandes, Lausanne, Switzerland (in French).

Xiang H (1999) Retrospect and prospect of cable-stayed bridges in China. Proceedings of the IABSE Conference-Cable-Stayed Bridges: Past, Present and Future, Malmö, Sweden, pp. 25-33.

Zellner W, Saul R and Svensson H (1984) Recent trend in the design of cable-stayed bridges. Proceedings of the 12th IABSE Congress, Vancouver, Canada, pp. 279-284.

\section{WHAT DO YOU THINK?}

To discuss this paper, please email up to 500 words to the editor at journals@ice.org.uk. Your contribution will be forwarded to the author(s) for a reply and, if considered appropriate by the editorial panel, will be published as discussion in a future issue of the journal.

Proceedings journals rely entirely on contributions sent in by civil engineering professionals, academics and students. Papers should be 2000-5000 words long (briefing papers should be 1000-2000 words long), with adequate illustrations and references. You can submit your paper online via www.icevirtuallibrary.com/content/journals, where you will also find detailed author guidelines. 